\title{
IONIC LIQUIDS DERIVATIVE OF 1H-IMIDAZOLE AS NOVEL REAGENTS, CATALYSTS AND SOLVENTS
}

\author{
V. Sargorovschi, N. Sucman, T. Iudin, D. Duca, E. Stingaci, D. Prodius, S. Pogrebnoi, \\ F. Macaev* \\ Institute of Chemistry of the Academy of Sciences of Moldova, \\ 3 Academy str., MD-2028, Chisinau, Moldova \\ Tel+373-22-739-754, Fax+373-22-739-954,*E-mail:flmacaev@cc.acad.md
}

\section{Dedicated to the member-correspondent of the ASM professor Turtă C.I. on his $\mathbf{7 0}^{\text {th }}$ birthday}

\begin{abstract}
Ionic liquids are becoming widely used in chemical processes. Taking this into account we focus on recent advances in the synthesis and the investigation of $1 H$-imidazole derived ionic liquids. The first part of this paper focuses on describing the developments in the synthesis and physical properties of 1,3-disubstituted imidazolium salts. The second part describes the application of these unique reagents, as catalysts and solvents in organic chemistry.
\end{abstract}

Keywords: $1 H$-imidazole, ionic liquids, reagents, catalysts, solvents, organic synthesis.

\section{Introduction}

$1 H$-Imidazole 1 is a structural fragment of numerous natural compounds as well as synthetic medicinal preparations [1]. Despite a wide variety of imidazole derivatives, organic and bioorganic syntheses as well as different fields of medicine continuously require novel biologically active compounds, reaction mediums, solvents and more efficient and environmentally friendly catalysts. One of promising research areas today is the chemistry of melted salts, which are usually called "ionic liquids". Ionic liquids in most cases are nitrogen-containing organic substances (Figure 1), except the derivatives of phosphorus, which account for not more than $10 \%$ of the total number of specific liquids described in the literature. Ionic liquids derived from $1 H$-imidazole $\mathbf{1}$ are one of the most representative and interesting groups due to their properties.

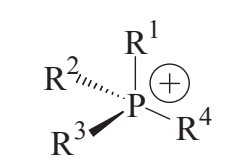

phosphonium<smiles></smiles>

imidazolium

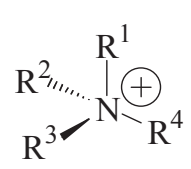

ammonium

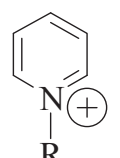

$\mathrm{R}$

pyridinium

common cations

$$
\mathrm{F}_{3} \mathrm{CO}_{2} \mathrm{~S}-\mathrm{N}-\mathrm{SO}_{2} \mathrm{CF}_{3}^{-} \quad \mathrm{PF}_{6}^{-} \quad \mathrm{CF}_{3} \mathrm{SO}_{3}^{-} \mathrm{BF}_{4}^{-}
$$

common anions

Figure 1

Literature data on the synthesis and investigation of ionic liquids based on diazole 1 were previously summarized in the monograph [2], as well as in a series of reviews [3-20]. In this review, an emphasis will be laid on the most meaningful and promising, in the authors' point of view, works on the synthesis and properties of ionic liquids, as well as those not discussed in the publications [1-20].

We shall begin the study of the chemical transformations of compound 1 with the analysis of the data of the synthesis of 1,3-dialkyl imidazolium salts. The second part of the review will focus on functionalized imidazolium salts. The third part will present the data on physical properties of imidazolium derivatives. Finally, data will be given on the use of imidazolium salts in organic synthesis, without any special sub-section dedicated to chiralic representatives. Questions regarding the synthesis and properties of $1 H-4,5$-dihydroimidazole and its derivatives, as well as of 2,4,5-substituted $1 \mathrm{H}$-imidazoles will not be discussed in this work. 


\subsection{Syntheses of 1,3-dialkylimidazolium salts}

Imidazole 1 has a five-member heterocyclic ring with two nitrogen atoms in positions 1 and 3. One of these nitrogen atoms is similar to the one in pyrrole and is responsible for the acidic properties of imidazole. The other one is similar to the nitrogen atom in pyridine and is responsible for the basic properties of imidazole. In general, it may be said that imidazole 1 has different properties, may react at different rates and gives various derivatives. Theoretically, the number of ionic liquids is indefinite and is limited only by the availability of necessary components: cations (organic) and anions (inorganic, organic and metal complexes). According to various estimates, the number of possible combinations of cations and anions in such liquids may reach $10^{18}$ [8].

The known methods of $\mathrm{N}$-alkylation of imidazole 1 include: the reaction with halo alkanes $\mathbf{2}$; the reaction of imidazole alkaline metals salts with halo alkanes 2; the reaction with trialkylphosphates; thermal decarboxylation of N-alkoxycarbonylimidazoles 7; the reaction with alcohols, in the presence of acidic catalysts; quaternization of $\mathrm{N}$-acylimidazoles 7 with subsequent deacylation and others (scheme 1) [21-27].

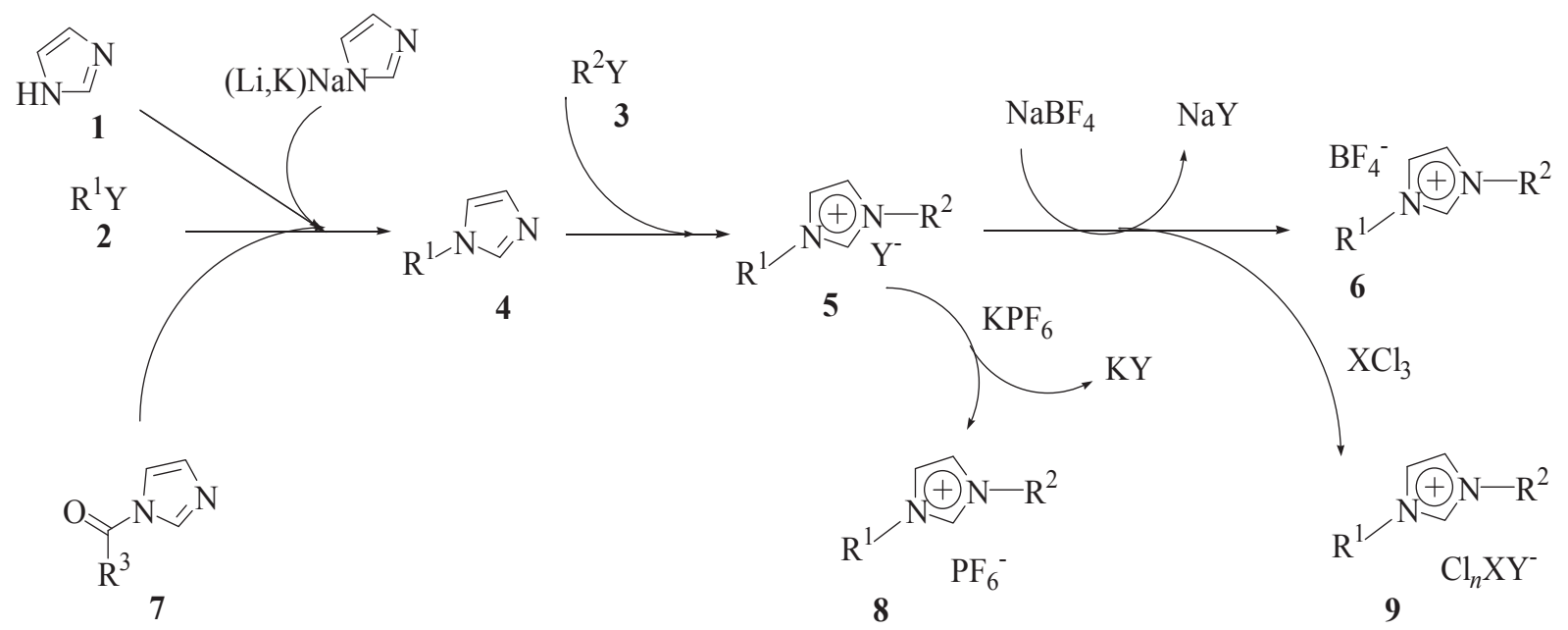

$\mathrm{R}^{1}=\mathrm{R}^{2}=$ alkil, $\mathrm{Bn}, \mathrm{SiMe}_{3}$, etc.; $\mathrm{R}^{3}=\mathrm{OH}$, alkil, $\mathrm{Ar}$, Im, etc; $\mathrm{X}=\mathrm{Na}, \mathrm{K}, \mathrm{Li}, \mathrm{Al}, \mathrm{Fe} ; \mathrm{Y}=\mathrm{Cl}, \mathrm{Br}, \mathrm{I}$

Scheme 1

It should also be mentioned that the synthesis of 3-bis-((S), 2-methyl-butyl)-1 $H$-imidazole-1-ium bromide (yield $21 \%)$ can be carried out by alkylation of trimethylsilylimidazole $4\left(\mathrm{R}^{\mathrm{l}}=\mathrm{SiMe}_{3}\right)$ with (S)-1-bromo-2-methylbutane [28].

Syntheses of mono N-substituted imidazoles 4 are performed in most cases in absolute conditions, or with the use of at least double equivalents of the initial $1 H$-imidazole 1.

Imidazoles $\mathbf{4}$ may react with the halo alkanes to give the salts $\mathbf{5}(\mathrm{Y}=$ halogen). This group of substances is involved in the reaction with $\mathrm{AlCl}_{3}$ or $\mathrm{FeCl}_{3}$, leading to ionic liquids of structure 9 [22, 29-32]. Borates $\mathbf{6}$, phosphates 8 and aluminates 9 can be synthesized by exchange reactions involving salts of the corresponding acids on N,N'- dialkyl imidazoles 5 [21-29, 33]. Also described are the syntheses of ionic liquids "in situ" directly in the reactor. In this case, the $\mathrm{N}$-alkyl imidazoles $\mathbf{4}$ and the halo metals are mixed together in the reactor, and the ionic liquid is formed just before the beginning of the chemical process or the catalytic reaction [7]. For the purification of ionic liquids from chlorideions electrochemical methods or ion exchange on ionites are used [27, 34, 35]. As to other approaches, the synthesis of ionic liquids with methyl and ethyl sulphate anions should be mentioned [36]. When synthesizing ionic liquids in the absence of a solvent (quaternization stage) a significant amount of heat is eliminated. The solution to this problem lies in performing the reaction under microwave or ultrasound radiation [37-40]. Eventually, the reaction product yield increases, the reaction time diminishes, the content of impurities in the product is minimized, and in some cases, the stage of the purification of the final product could be avoided.

\subsection{Syntheses of functionalized 1,3-disubstituted imidazolium salts}

In addition to the above-mentioned salts, derivatives of 11-14 with functional groups in side chain are also known (scheme 2). 


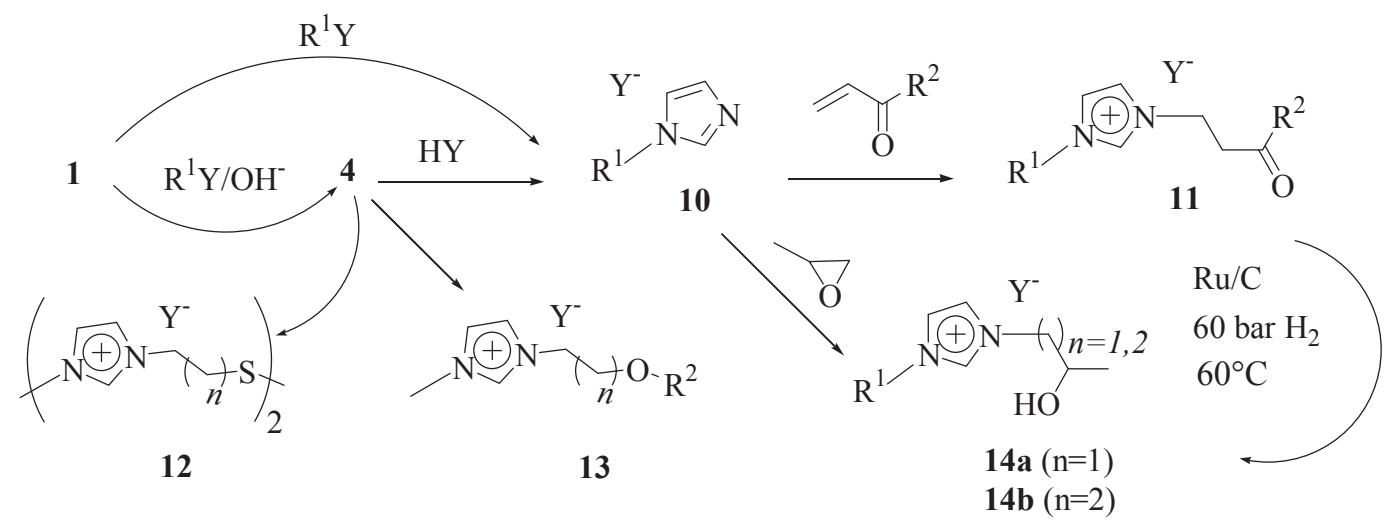

$\mathrm{R}^{1}=$ alkil, Bn, etc.; $\mathrm{R}^{2}=\mathrm{H}, \mathrm{OH}$, alkil, O-alkyl, etc; $\mathrm{Y}=\mathrm{Cl}, \mathrm{Br}, \mathrm{I}, \mathrm{BF}_{4}, \mathrm{PF}_{6}, \mathrm{MeSO}_{3},\left(\mathrm{CF}_{3} \mathrm{SO}_{2}\right)_{2} \mathrm{~N}$

\section{Scheme 2}

Imidazolium salts $\mathbf{1 0}$ are added to $\alpha, \beta$-unsaturated carbonyl compounds to give salt $\mathbf{1 1}$. This is called the Michael reaction and it involves conjugate addition. [41]. Variants of functional group such as ether or thio- may be present in the final substrates $\mathbf{1 2}$ or $\mathbf{1 3}[6,23,27,42,43]$.

Hydroxy functionalized ionic liquids $\mathbf{1 4 a}$ can be prepared by the reduction of ketone $\mathbf{1 1}\left(\mathrm{R}^{2}=\mathrm{Me}\right)$ or the treatment of 2-methyloxirane with salts $\mathbf{1 0}$ [44, 45]. In addition to the above-mentioned ionic liquids primary alcohols $\mathbf{1 3}$ may be synthesized directly by quaternization 4 [44].

The synthesis of imidazolium salts with amino- [46-49], carboxy-, sulfo- and nitrile groups in the side chain should also be mentioned. Imidazole 1 easily transforms into salts 16. There are many reagents that are added to imidazoles 4,15 according to (scheme 3). The same result can be achieved in one step with carboxy-functionalized imidazoles 17 [56-60].

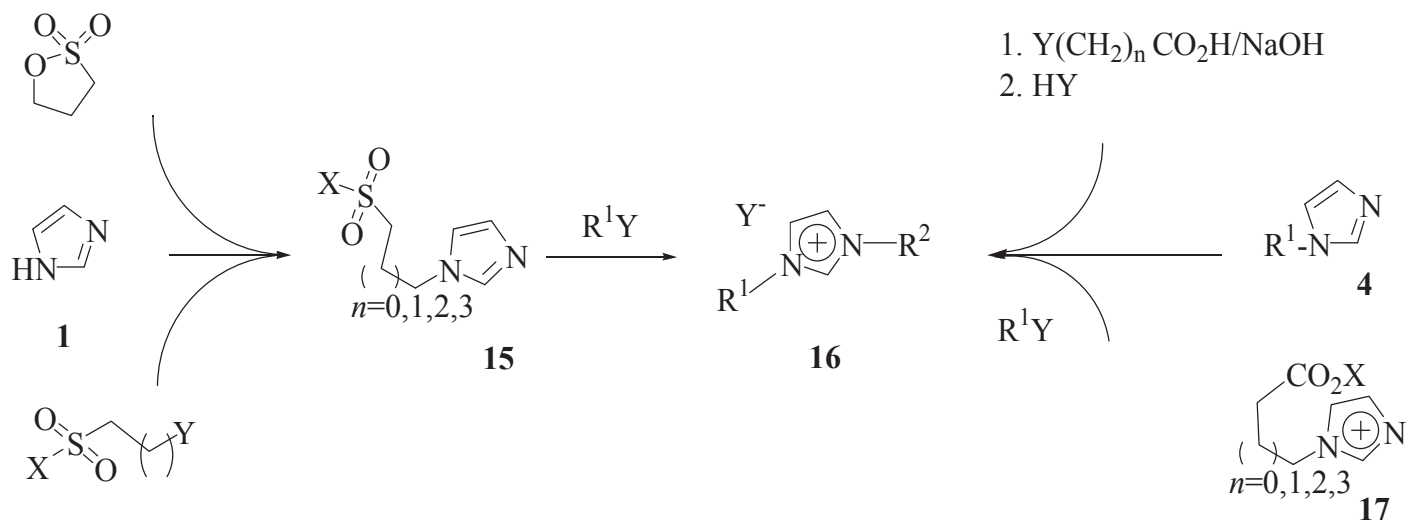

$\mathrm{R}^{1}=$ alkil, $\mathrm{Bn},\left(\mathrm{CH}_{2}\right)_{n} \mathrm{CO}_{2} \mathrm{H}$, etc.; $\mathrm{X}=\mathrm{Cl}, \mathrm{H}, \mathrm{OH} ; \mathrm{Y}=\mathrm{Cl}, \mathrm{Br}, \mathrm{I}, \mathrm{BF}_{4}, \mathrm{PF}_{6}, \mathrm{HSO}_{4}$

\section{Scheme 3}

Specialized literature also describes the precursors of carboxy-functionalized imidazolium salts (scheme 4) [61-69].

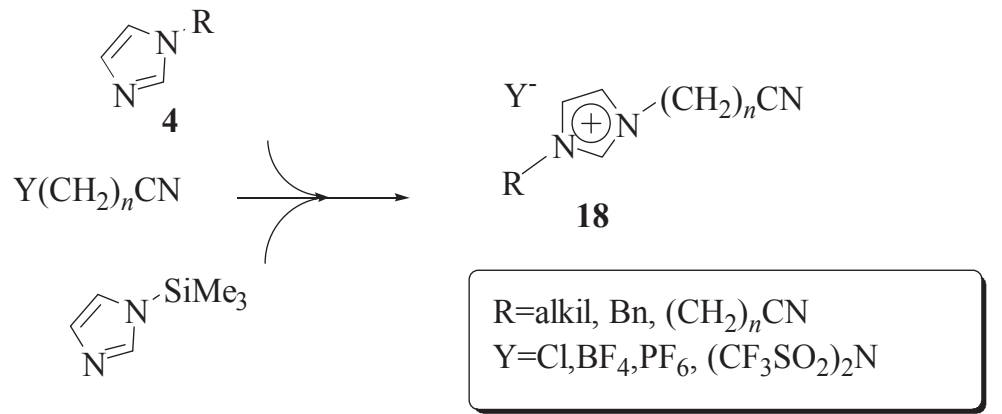

Scheme 4 
There are two possible ways. The initial product is always mono-substituted imidazoles.

Reaction has been performed on a number of imidazoles, including $1 H$-imidazolyl(trimethyl)silane. In this case symmetrically dinitrile imidazole chlorides are obtained. The anionic exchange of chlorides with $\mathrm{HPF}_{6}, \mathrm{NaBF}_{4}$ and LiTf $_{2} \mathrm{~N}$ gives the corresponding imidazolium salts $\mathbf{1 8}$.

The synthesis of the functionalized ionic liquids with the primary amino group in the side chain is presented in (scheme 5) [70].

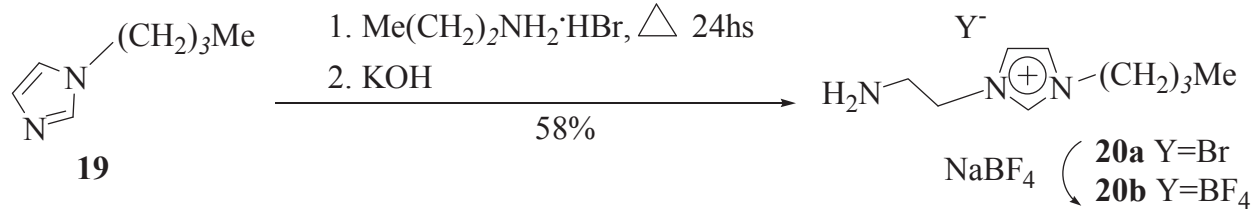

\section{Scheme 5}

The reaction of imidazole 19 with 3-brompropylamine is easily carried out at room temperature. $\mathrm{NaBF}_{4}$ are added to aqueous ethanol solution of bromide 20a to give ionic liquid 20b.

Methyloxirane group can be introduced into the 1 and 4 positions of imidazole 1 by the treatment with 2-chloromethyloxirane following the quaternization of the product $\mathbf{2 1}$ until the chloride 22a (scheme 6) [71].
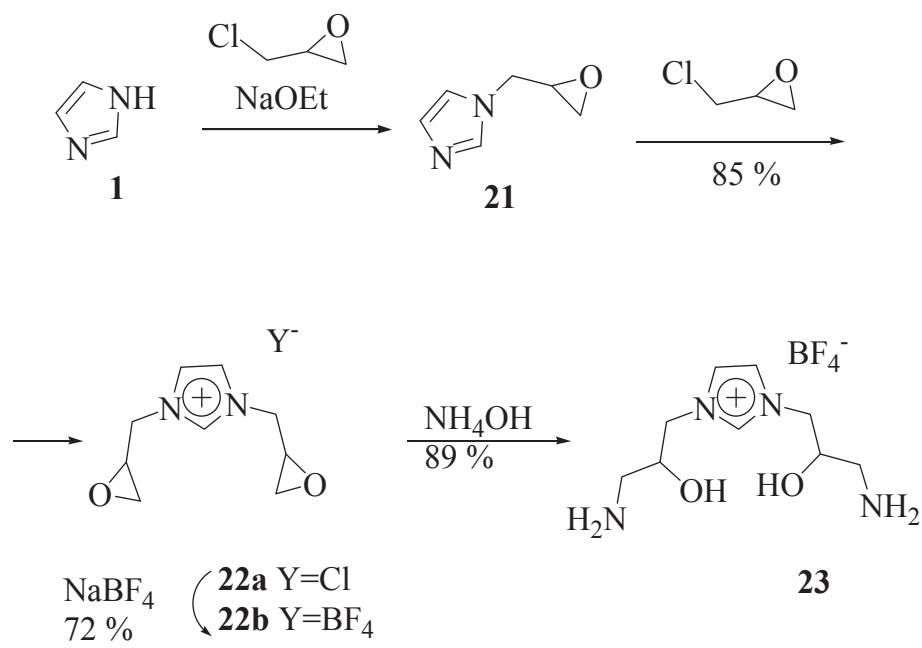

\section{Scheme 6}

The opening of the epoxides $\mathbf{2 2} \mathbf{b}$ to amino-alcohols $\mathbf{2 3}$ has been accomplished at $2 \mathrm{~atm}$.

Lately, the number of the investigations dedicated to linking or immobilizing the ionic liquids on $\mathrm{Al}_{2} \mathrm{O}_{3}, \mathrm{SiO}_{2}$, microporous polymers, clays and media based on coals and mesoporous materials has increased.

Polymers immobilizing ionic liquids can be prepared in a number of ways. In one method, chiral imidazolium salts 25a-c have been obtained starting with imidazole $\mathbf{2 4}$ according to (scheme 7) [72].

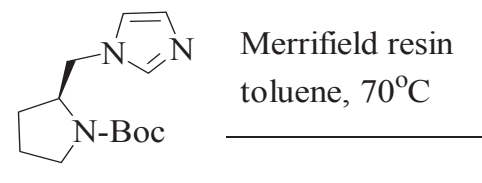

24

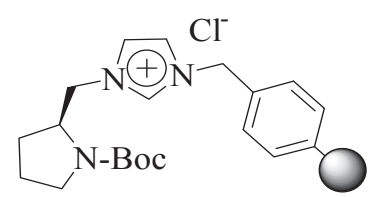

$25 \mathbf{a}$

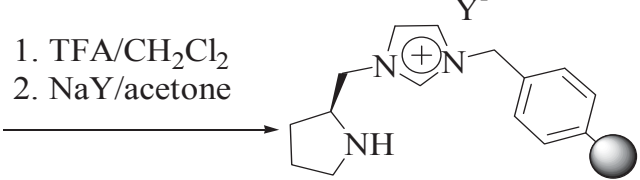

25b $\mathrm{Y}=\mathrm{PF}_{6}$ 25c $\mathrm{Y}=\mathrm{BF}_{4}$

Scheme 7

If the activated silica gel contains a functional group such as $\mathrm{OH}$, corresponding ionic liquids $\mathbf{2 7}$ may be the products from chloride $\mathbf{2 6}$ or salts $\mathbf{2 8}$ (scheme 8 ). 


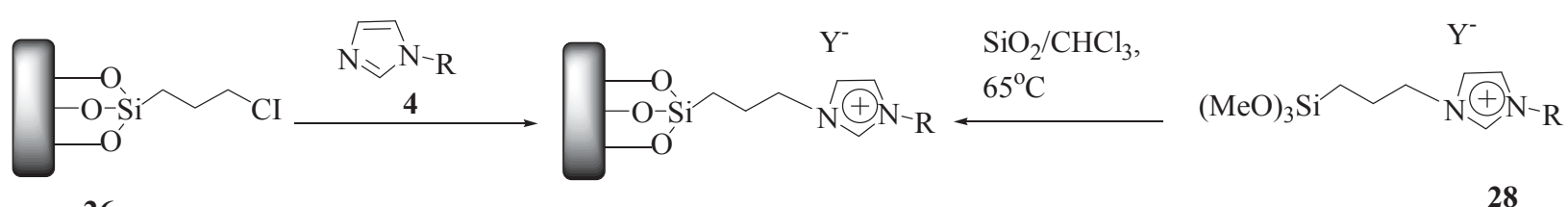

26

$27 \mathrm{Y}=\mathrm{Cl}, \mathrm{Br}, \mathrm{I}, \mathrm{PF}_{6}, \mathrm{BF}_{4}$ or Proline

Scheme 8

This group of substances demonstrates the advantages over homogeneous ion liquids in simplifying the separation after the reaction, facilitating the regeneration which follows reusing, etc [73-80 62-69].

\subsection{Physical properties of 1,3 -disubstituted imidazolium salts}

The theoretical dependence of the melting temperature of the discussed salts on the nature of the anion and the substituents has not been determined. Only the correlation between the melting temperature and the length of the radical in typical ionic liquids, which has a clear minimum: for $\mathrm{C}_{3}-\mathrm{C}_{5}$ the interval lies between $-10^{\circ} \mathrm{C}$ and $+10^{\circ} \mathrm{C}$ has been mentioned. Reducing the length of the radical leads to the increase of the "ionicity", which eventually leads to a higher melting temperature, while increasing the size of the anion leads to the decrease of the melting temperature. This can also be facilitated by the introduction of fluorine in the structure of ionic liquids. High viscosity and density are characteristic of ionic liquids, which increase when the replacing of chlorine or fluorine by bromine takes place.

Numbers of imidazolium salts have different stability. For example, ionic liquids containing $\mathrm{AlCl}_{3}$ decompose in the presence of water or at the elevated temperature. An example of thermally stable ionic liquid is 1-ethyl-3-methyl imidazole triphtalate $\left.[\mathrm{emim}]\left(\mathrm{CF}_{3} \mathrm{SO}_{2}\right)_{2} \mathrm{~N}\right] 2$, which is resistant to heating up to $450{ }^{\circ} \mathrm{C}$ [23]. It should be noted that many imidazolium ionic liquids can be used at the temperature up to $200^{\circ} \mathrm{C}$ (see table 1 ).

Table 1

Physical properties and solubility of imidazolium salts 30a-e

\begin{tabular}{|c|c|c|c|c|c|c|c|c|}
\hline \multirow[t]{2}{*}{ Salt } & \multirow{2}{*}{$\begin{array}{l}\text { M.p./ } \\
\text { color }\end{array}$} & \multirow{2}{*}{$\begin{array}{c}\text { Temperature } \\
\text { range of liquid } \\
\text { phase }\end{array}$} & \multicolumn{6}{|c|}{ Solubility in solvents } \\
\hline & & & $\mathrm{H}_{2} \mathrm{O}$ & МeOH & Acetone & $\mathrm{CHCl}_{3}$ & hexane & toluene \\
\hline $\begin{array}{c}{[\mathrm{bmim}]\left[\mathrm{BF}_{4}\right]} \\
\mathbf{3 0 a}\end{array}$ & $\begin{array}{l}226.06 / \\
\text { Yellow }\end{array}$ & $-48.96 /+399.20$ & + & + & + & + & - & - \\
\hline $\begin{array}{c}{[\mathrm{bmim}]\left[\mathrm{PF}_{6}\right]} \\
\mathbf{3 0 b}\end{array}$ & $\begin{array}{l}284.48 / \\
\text { Yellow }\end{array}$ & $13.50 /+388.34$ & - & + & + & + & - & - \\
\hline $\begin{array}{c}{[\mathrm{bmim}]\left[\mathrm{AlCl}_{4}\right]} \\
\mathbf{3 0 c}\end{array}$ & $\begin{array}{l}\text { 154.01/ } \\
\text { Brown }\end{array}$ & $-88.69 /+263.10$ & 0 & 0 & + & + & - & + \\
\hline$[\mathrm{bmim}]\left[\mathrm{Br} / \mathrm{AlCl}_{3}\right]$ 30d & $\begin{array}{c}154.01 / \\
\text { Black }\end{array}$ & $13.61 /+272.51$ & 0 & 0 & + & - & - & - \\
\hline$\underset{\mathbf{3 0 e}}{[\mathrm{emim}]\left[\mathrm{PF}_{6}\right]}$ & $\begin{array}{l}256,13 / \\
\text { Yellow }\end{array}$ & $2.71 /+304.65$ & - & - & + & + & - & - \\
\hline
\end{tabular}

(+) - mixes; (-) - doesn't mix; (0) - interacts with the salt.

The solubility of different substances in imidazolium salts 30a-e depends on the dielectric permeability, polarity of both types of products, etc. It should be noted that hydrocarbons possess limited solubility in imidazolium salts. This property is used to simplify their application in two-phase systems, including separation procedures. It has been established that increasing the chain length of the substituent at nitrogen atoms can increase the solubility of olefins and aromatic hydrocarbons.

One of interesting properties of ionic liquids is presented below. Complexes of imidazolium salt with $\mathrm{Cl}^{-}, \mathrm{Br}^{-}, \mathrm{I}^{-}$, $\mathrm{BF}_{4}^{-}, \mathrm{CF}_{3} \mathrm{CO}_{2}^{-}, \mathrm{CF}_{3} \mathrm{SO}_{3}^{-}$form homogeneous mixtures with $\mathrm{H}_{2} \mathrm{O}$, while salts with $\left(\mathrm{CF}_{3} \mathrm{SO}_{2}\right)_{2} \mathrm{~N}^{-}$and $\mathrm{PF}_{6}^{-}$practically don't mix with water and can be used in two-phase systems with water.

One of the tasks solved with the help of ionic liquids includes the increase in the solubility of salts and transitionmetal complexes, frequently used in homogeneous catalysis, as they are characterized by low solubility in organic solvent. This makes imidazolium salts good alternatives to traditional solvents.

\subsection{1,3-Disubstituted imidazolium salts in organic synthesis}

It is known that up to $90 \%$ of chemical processes on earth occur under catalytic conditions [81]. High specificity and/or efficiency are the main requirements of catalysts. 
In the last decade we witnessed a significant increase of the interest in the use of 1,3-disubstitutedimidazole salts in organic synthesis. This is due to the fact that they are positively different from traditional solvents in their resistance towards oxidative actions, their non-volatility, and, in some cases, their catalytic activity.

Imidazolium salts based on metals chlorides are considered an alternative to the traditional homogeneous and heterogeneous catalysts like $\mathrm{AlCl}_{3}$, etc. These kinds of ionic liquids are strong Lewis acids, immobilized in the phase of ionic liquid by analogy with catalytic systems on solid media.

The processes associated with the chemistry of carbocations are one of the important areas that would allow us to explore the possibilities of the use of ionic liquids. Primary formation of reactive carbocations may occur in ionic liquids under the action of Lewis acids on the haloacyl- or alkyl derivatives, during the protonation of esters or molecules containing multiple links, etc. The reactions of alkylation and acylation of aromatic hydrocarbons according to FridelKraft reaction (scheme 9) should be mentioned as an example [48, 82-89].

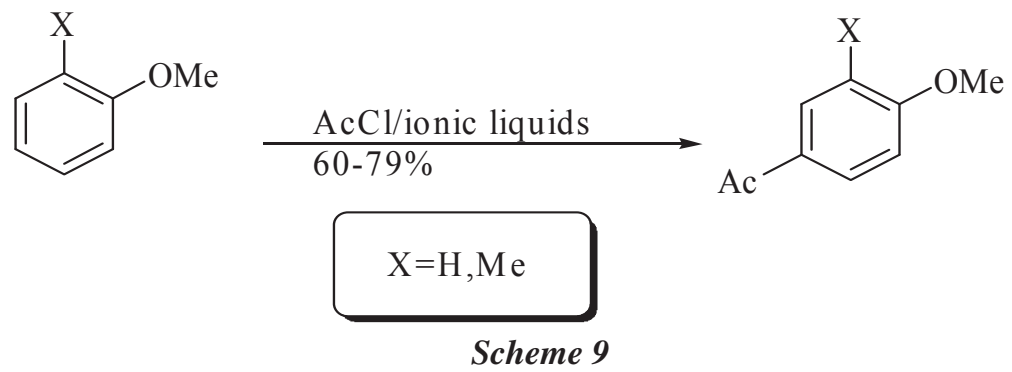

An example of the relationship of the nature of the anion on the chemo- and regioselectivity is illustrated on the reaction of nitration, chlorination and oxidation of toluene (scheme 10) [90].

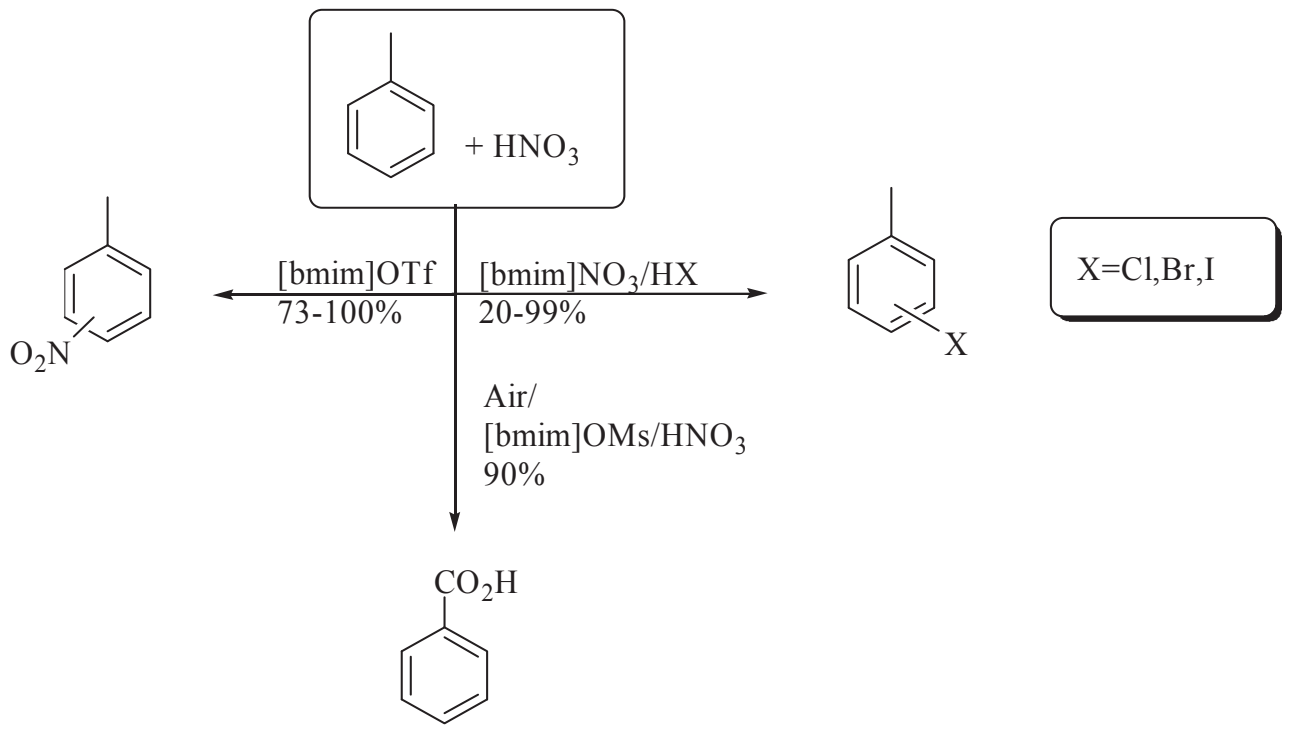

Scheme 10

The authors have shown that this approach is acceptable for benzene, biphenyl, anisole and naphthalene.

It should be emphasized that these articles and patents described alkylation and acylation of aromatic hydrocarbons in ionic liquids. This area is not limited to the reactions of electrophilic substitution and there are a number of publications on the use of ionic liquids in the alkylation of isobutene by butenes with the formation of isooctane or benzene fractions.

Another example of the alkylation is the C-alkylation of phenol, 2-naphthol or indole with yield up to 99\% [91, 92, $80,81]$. One should also mention the communication about the use of the mixture of ionic liquid/mineral acid for the decomposition of methyl ether 31a to alcohol 31b (scheme 11) [93 82]. 


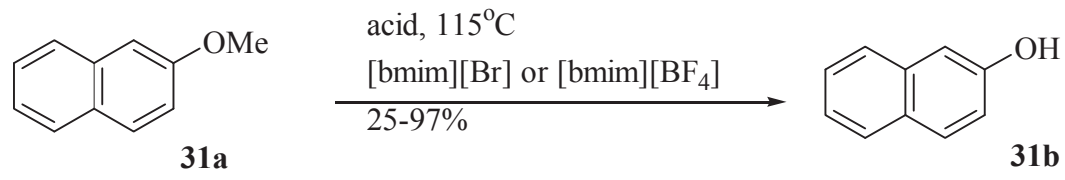

acid $=\mathrm{HCl}(35 \%), \mathrm{HBr}(47 \%), \mathrm{H}_{2} \mathrm{SO}_{4}(50 \%), \mathrm{AcOH}, \mathrm{p}-\mathrm{TsOH}, \mathrm{MsOH}$

\section{Scheme 11}

the reactions with similar mechanisms to the reactions of alkylation, such as etherification, were also investigated in ionic liquids [94-96, 83-85].

The oxidation of primary and secondary alcohols $\mathbf{3 2}$ to carbonyl derivatives $\mathbf{3 3}$ under the action of $\mathbf{3 4}$ in aqueous solutions of ionic liquids is shown in (scheme 12) [97].<smiles>O=C1OI(=O)(O)c2ccccc21</smiles>

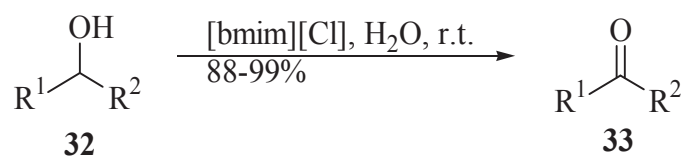

\section{Scheme 12}

The oxidation of ketones and aldehydes $\mathbf{3 5}$ according to the Baeyer-Villiger reaction in the solution of ionic liquids was proposed by a group of Indian chemists (scheme 13) [98].

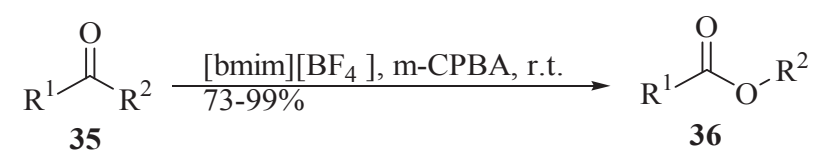

\section{Scheme 13}

Catalytic processes involving ionic liquids give a new impulse to developing processes of dimerization, oligomerization, polymerization and copolymerization [99]. Isomerization of 2-methyl-3-buthenenitrile $\mathbf{3 7}$ in 3 -pentenonitrile 38 was performed in a two-phase system (ionic liquid/n-heptane/ Ni(cod) $)_{2},\left[\mathrm{Ph}_{2} \mathrm{P} m\right.$ - $\left.\mathrm{PhSO}_{3} \mathrm{Na}\right)$ with $96 \%$ conversion and 93\% selectivity (scheme 14) [100-106].

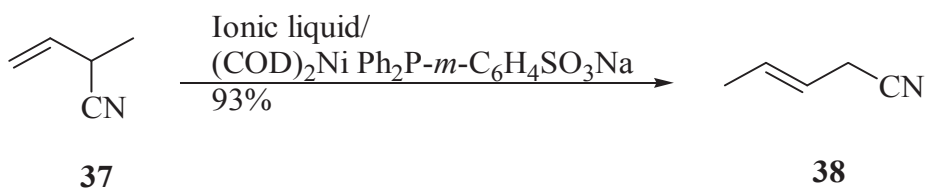

Scheme 14

It has been found that this system does not lead to the isomerization or the degradation of the n-heptane itself. The latter phenomenon has been observed with $\mathrm{Al}_{2} \mathrm{Cl}_{7}{ }_{7}^{-}$anion containing ionic liquids [107-113].

A group of researchers [114,115] reported the possibility of using ionic liquids $\mathbf{4 0}$ to perform the Morita-BaylisHillman reactions (scheme 15).

The authors suggested using amino- and amino hydroxy- functionalized salts 39a-c for the synthesis of ionic liquids 40, which catalyze the 1,3-adition of methyl acrylate to $p$-chlorbenzaldehyde. It was shown that the yield of alcohol $\mathbf{4 1}$ varies greatly from the nature of the solvent. The best yield was obtained using $\mathrm{MeOH}$, while replacing it by ionic liquids $\mathbf{3 0 a}$ or $\mathbf{3 0 b}$ reduced the yield to $13 \%$ (scheme 15 ). 

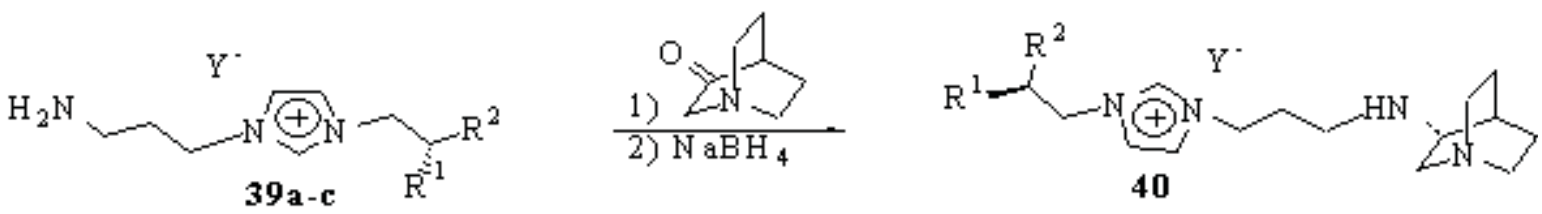

$\mathrm{R}^{1}=\mathrm{H}, \mathrm{Me} ; \mathrm{R}^{2}=\mathrm{OH}, \mathrm{Et} ; \mathrm{Y}=\mathrm{B}+\mathrm{BF}_{4}, \mathrm{PF}_{6}$

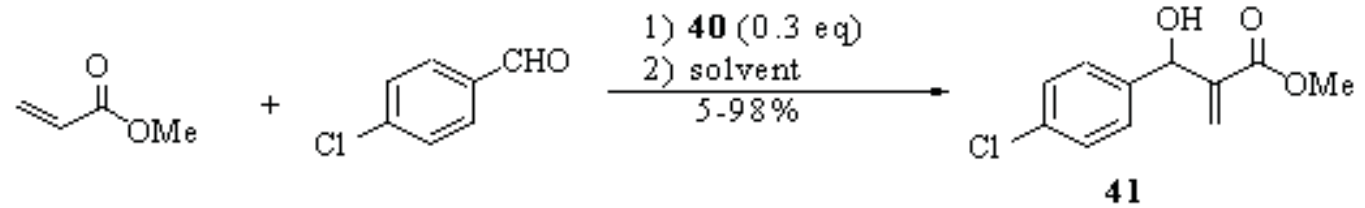

\section{Scheme 15}

The synthesis and catalytic properties of another type of imidazolium salt $\mathbf{4 3}$ is described in [116]. The key intermediate 42 was obtained from the methyl ether of lactic acid and naphthol $\mathbf{3 1 b}$ according to (scheme 16).
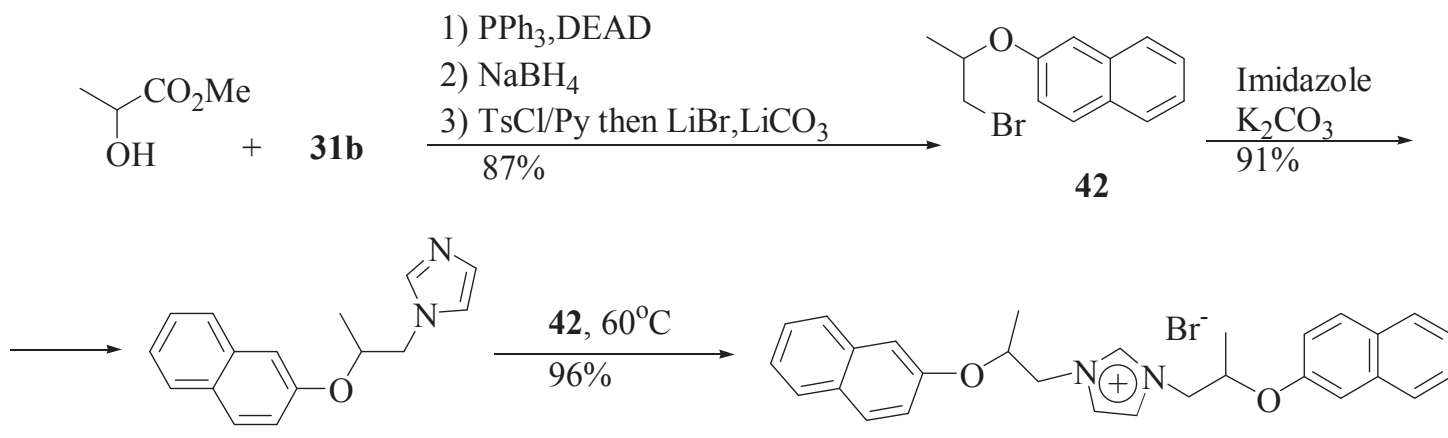

43

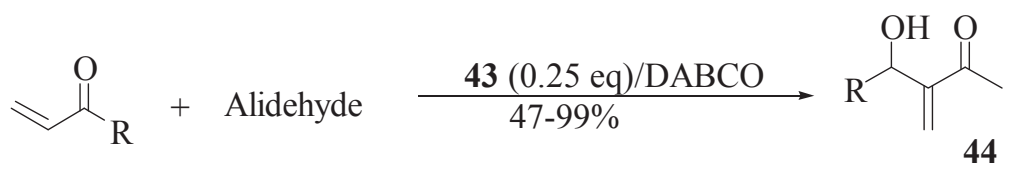

$\mathrm{R}=\mathrm{Me}$, OMe;

Aldehyde $=p$-nirtobenzaldehyde, methyl 4-formylbenzoate,

4-(trifluoromethyl)benzaldehyde, 2-naphthaldehyde, 3-phenylpropionaldehyde,

4-biphenylcarboxaldehyde, 4-methylbenzaldehyde, 4-chlorobenzaldehyde etc

\section{Scheme 16}

The reaction yield of allylic alcohols 44 ranges from $47 \%$ to $99 \%$ and depends on the nature of the aldehyde.

Ionic liquids have been applied to superacidic cyclization of the terpenic phenyl sulphones to bicyclic compounds 45, 46 (scheme 17) [117]. 


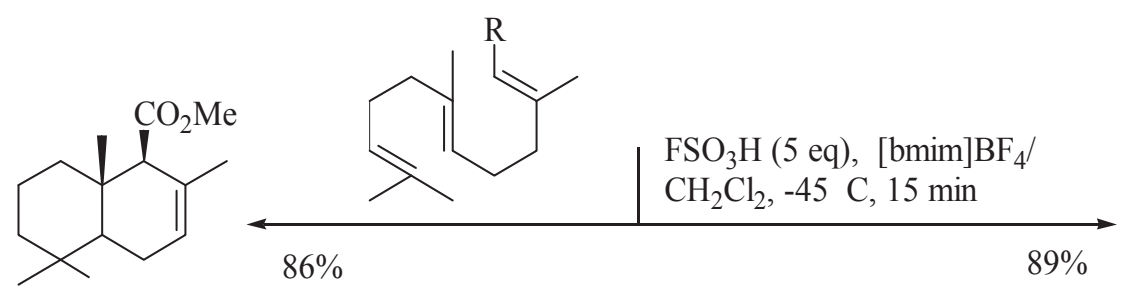

45

$$
\mathrm{R}=\mathrm{CO}_{2} \mathrm{Me} \text { or } \mathrm{CH}_{2} \mathrm{SO}_{2} \mathrm{Ph}
$$

Scheme 17

Similar reactions can be carried out on substances stable in acid media.

An Indian group of researchers reported the use of chloride of methylbutylimidazole 47a for the thiocyanation of alkyl halogenides through the ionic liquid 47b (scheme 18) [118].

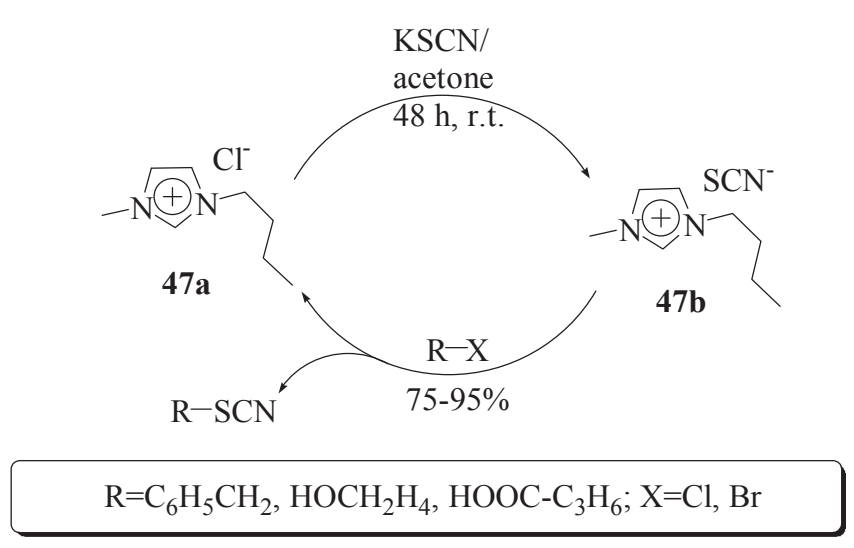

\section{Scheme 18}

There are publications regarding the use of ionic liquids in the synthesis of the biologically active thioureas and ureas $[119,120]$. The strategy of the synthesis of 2-thioxo tetrahydropyrimidin-4-(1H)-ones is shown in (scheme 19). 


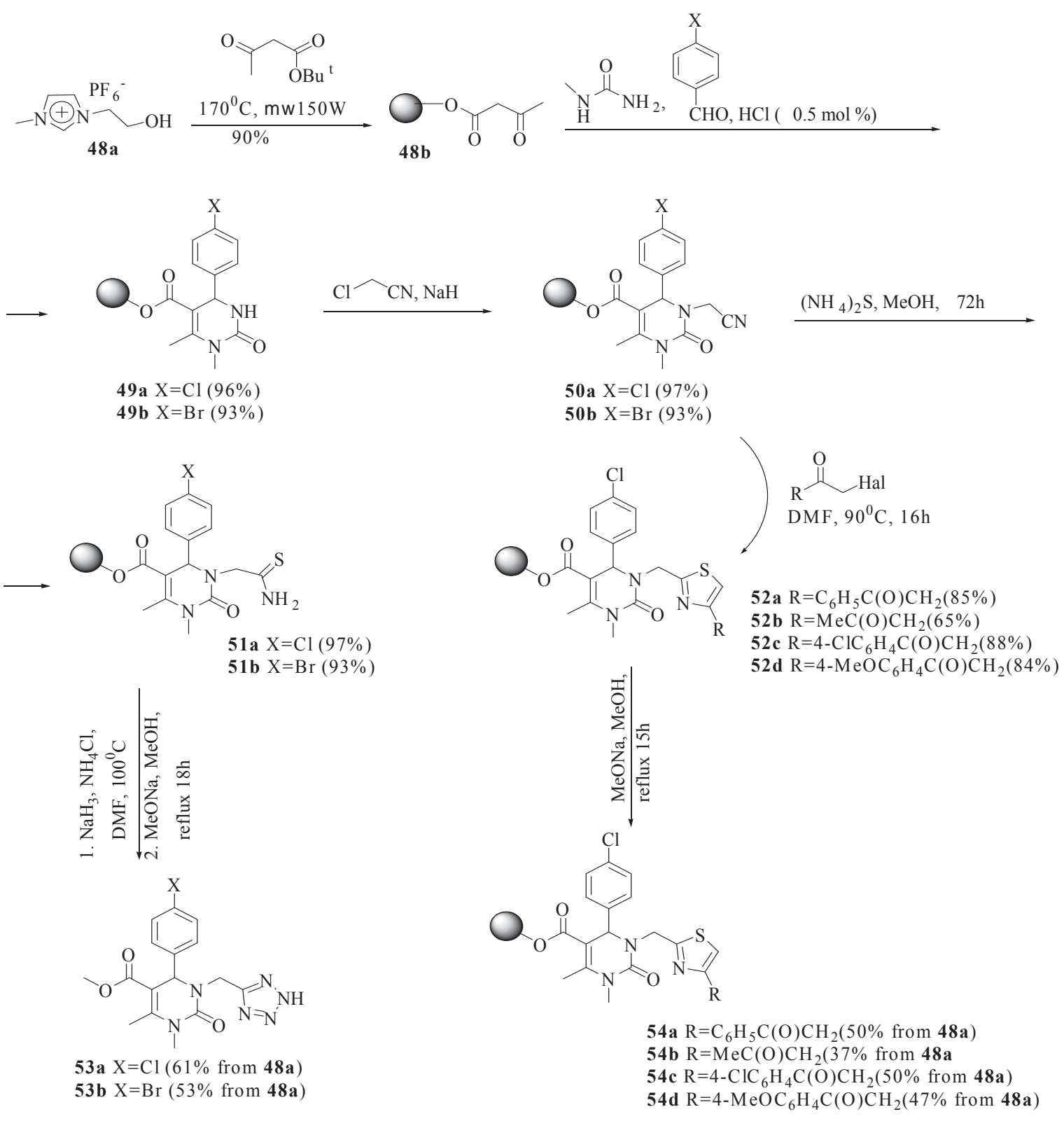

Scheme 19

The trans-esterification of acetoacetic ester of hydroxy-functionalized ionic liquid 48a under microwave radiation gives ester 48b. The cyclocondensation of $\beta$-ketoester, N-methylurea with aromatic aldehydes according to Biginelli reaction occurs with the formation of cyclic products $49 \mathbf{a}, \mathbf{b}$. Tetra-substituted ureas $\mathbf{5 0 a}, \mathbf{b}$ were used to obtain the ionic liquids 51a,b, 52a-d. The final stage of obtaining tetrazoles 53a,b and thiazoles 54a-d was realized by a long heating of salts 51a,b and 52a-d with sodium methylate in $\mathrm{MeOH}$.

Analogously built 3,4-dihydropyrimidine-2(1 H)-ones 55a-e have been synthesized (scheme 20) [121]. 


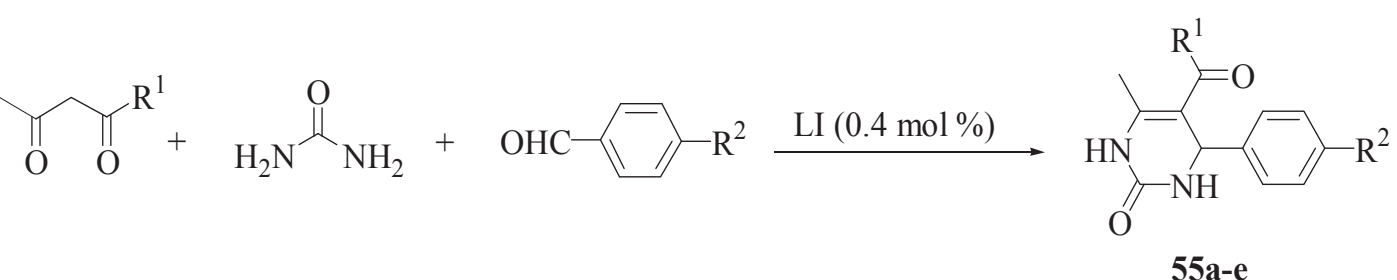

a: $\mathrm{R}^{1}=\mathrm{OC}_{2} \mathrm{H}_{5}, \mathrm{R}^{2}=\mathrm{C}_{6} \mathrm{H}_{5}(85 \%$, cat (30a) ; 94\%, cat (30b)

b: $\mathrm{R}^{1}=\mathrm{OC}_{2} \mathrm{H}_{5}, \mathrm{R}^{2}=4-\mathrm{MeOC}_{6} \mathrm{H}_{4}(95 \%$, cat (30a) $; 98 \%$, cat (30b)

c: $\mathrm{R}^{1}=\mathrm{OC}_{2} \mathrm{H}_{5}, \mathrm{R}^{2}=4-\mathrm{ClC}_{6} \mathrm{H}_{4}(96 \%$, cat (30a) $; 98 \%$, cat (30b)

d: $\mathrm{R}^{1}=\mathrm{OC}_{2} \mathrm{H}_{5}, \mathrm{R}^{2}=4-\mathrm{NO}_{2} \mathrm{C}_{6} \mathrm{H}_{4}(90 \%$, cat (30a) ; $92 \%$, cat (30b)

e: $\mathrm{R}^{1}=\mathrm{Me}, \mathrm{R}^{2}=4-\mathrm{NO}_{2} \mathrm{C}_{6} \mathrm{H}_{4}(92 \%)$, cat (30a)

\section{Scheme 20}

Under the action of $m$-chlorperbenzoic acid, cyclic and non-cyclic ketones are to esters or lactones oxidized according to Baeyer-Villiger in the solution of the tetrafluorborate 30a (scheme 21) [112,122].

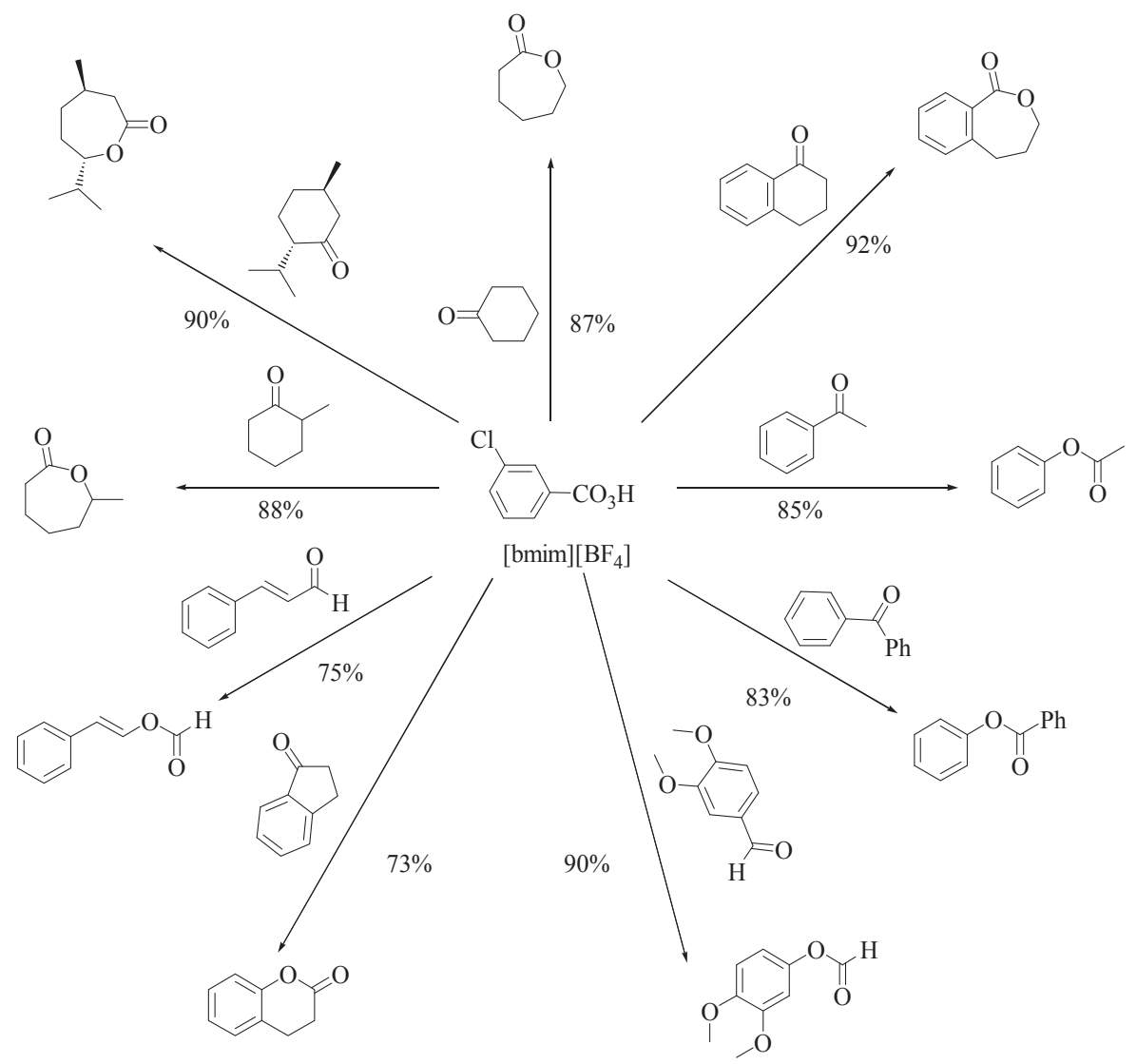

Scheme 21

The ionic liquid plays the role of solvent and activator of meta-chlorperbenzoic acid. On the other hand, the tetrafluorborate 30a is suggested for the epoxidation of olefins $\mathbf{5 6}$ to oxides $\mathbf{5 7}$ in the system with $\mathrm{H}_{2} \mathrm{O}_{2} / \mathrm{Me}_{4} \mathrm{NHCO}_{3} / \mathrm{MnSO}_{4}$ (scheme 22) [123]. 


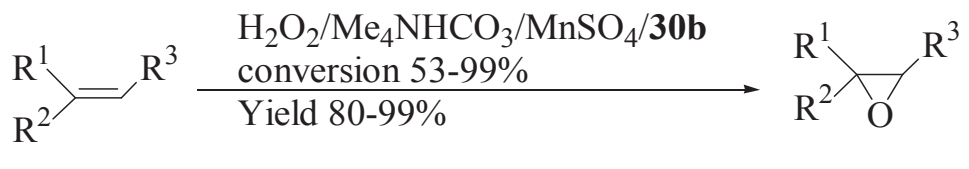

56

57

\section{Scheme 22}

Another type of epoxidation according to the Corey-Chaykovsky reaction was performed by $\mathrm{Me}_{3} \mathrm{SI}$ and $\mathrm{KOH}$ in the solution of hexafluorphosphate $\mathbf{3 0 b}$ (scheme 23) [124].

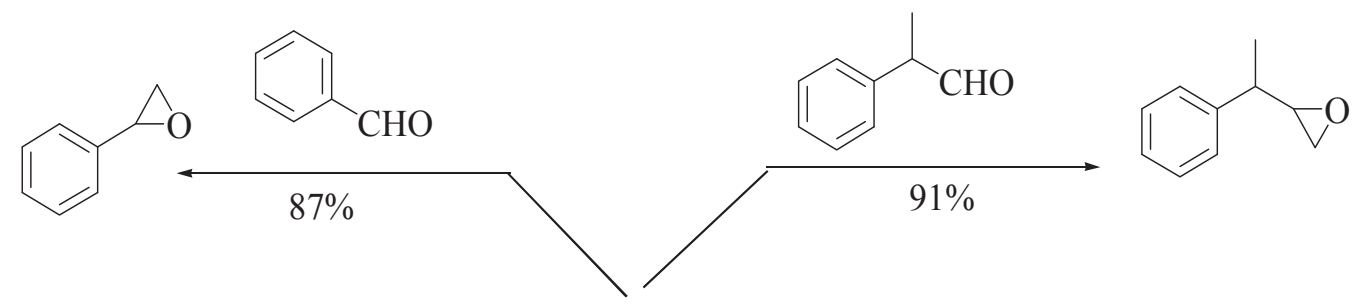

$\mathrm{Me}_{3} \mathrm{SI}, \mathrm{KOH}, \mathbf{3 0 b}$

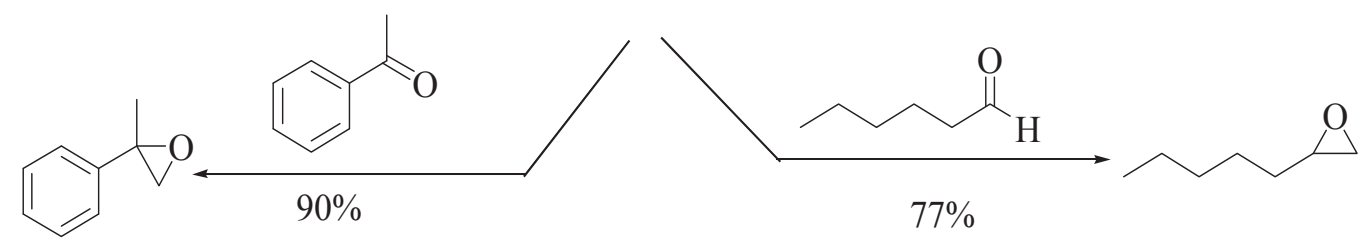

Scheme 23

Epoxides 58, 59 may be transformed into thioranes 60, 61 under the action of the mixture KSCN/ionic liquid/ $\mathrm{H}_{2} \mathrm{O}_{2}$ (scheme 24) [125].

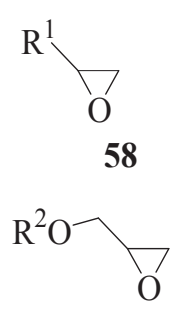

59

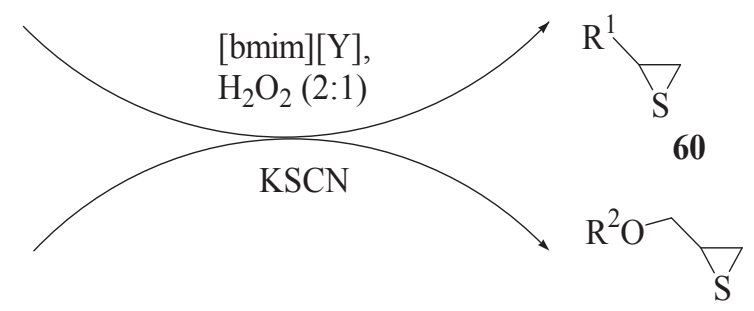

61

$$
\begin{array}{ll}
\mathrm{R}^{1}=\mathrm{C}_{6} \mathrm{H}_{5}\left(\mathrm{Y}=\mathrm{BF}_{4}, 89 \% ; \mathrm{Y}=\mathrm{PF}_{6}, 93 \%\right) & \mathrm{R}^{2}=\mathrm{C}_{6} \mathrm{H}_{5}\left(\mathrm{Y}=\mathrm{BF}_{4}, 91 \% ; \mathrm{Y}=\mathrm{PF}_{6}, 95 \%\right) \\
\mathrm{R}^{1}=\mathrm{CH}_{2} \mathrm{Cl}\left(\mathrm{Y}=\mathrm{BF}_{4}, 80 \% ; \mathrm{Y}=\mathrm{PF}_{6}, 91 \%\right) & \mathrm{R}^{2}=\operatorname{allyl}\left(\mathrm{Y}=\mathrm{BF}_{4}, 85 \% ; \mathrm{Y}=\mathrm{PF}_{6}, 92 \%\right) \\
\left.\mathrm{R}^{1}=\mathrm{n}-\mathrm{h} \operatorname{cxyl}\left(\mathrm{Y}=\mathrm{BF}_{4}, 87 \%\right) ; \mathrm{Y}=\mathrm{PF}_{6}, 92 \%\right) & \mathrm{R}^{2}=\mathrm{n}-\mathrm{butyl}\left(\mathrm{Y}=\mathrm{BF}_{4}, 87 \% ; \mathrm{Y}=\mathrm{PF}_{6}, 90 \%\right) \\
\mathrm{R}^{2}=\mathrm{C}_{6} \mathrm{H}_{5}\left(\mathrm{Y}=\mathrm{BF}_{4}, 91 \% ; \mathrm{Y}=\mathrm{PF}_{6}, 95 \%\right) & \mathrm{R}^{2}=4-\mathrm{Cl}_{6}-\mathrm{C}_{6} \mathrm{H}_{4}\left(\mathrm{Y}=\mathrm{BF}_{4}, 85 \% ; \mathrm{Y}=\mathrm{PF}_{6}, 96 \%\right) \\
\mathrm{R}^{2}=4-\mathrm{MeO}-\mathrm{C}_{6} \mathrm{H}_{4}\left(\mathrm{Y}=\mathrm{BF}_{4}, 89 \% ; \mathrm{Y}=\mathrm{PF}_{6}, 92 \%\right) & \mathrm{R}^{2}=4-\mathrm{Me}-\mathrm{C}_{6} \mathrm{H}_{4}\left(\mathrm{Y}=\mathrm{BF}_{4}, 90 \% ; \mathrm{Y}=\mathrm{PF}_{6}, 95 \%\right)
\end{array}
$$

\section{Scheme 24}

The authors have shown that the sulfides $\mathbf{6 0 , 6 1}$ are formed with the yield up to $95 \%$.

In addition, the group has reported the synthesis of $\beta$-ketosulfides 63a-e, 64a-c, 66a-d by conjugated addition of thiols to enones 62a, 62 b, 65 in the mixture of hexafluorphosphate $\mathbf{3 0 b} / \mathrm{H}_{2} \mathrm{O}$ (scheme 25) [126]. 


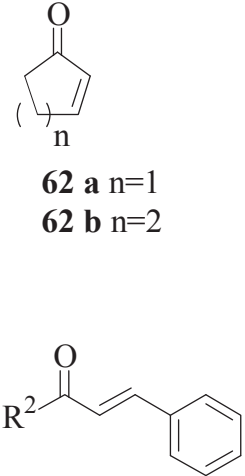

65
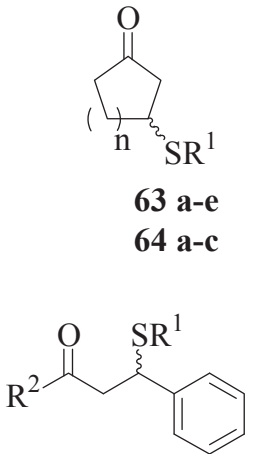

66 a-d

63a $\mathrm{R}^{1}=\mathrm{C}_{6} \mathrm{H}_{5}, \mathrm{n}=2,10 \mathrm{~min}, 95 \% ; \mathbf{6 3 b} \mathrm{R}^{1}=4-\mathrm{Cl}-\mathrm{C}_{6} \mathrm{H}_{4}, \mathrm{n}=2,15 \mathrm{~min}, 93 \%$;

63c $\mathrm{R}^{1}=4-\mathrm{MeO}-\mathrm{C}_{6} \mathrm{H}_{4}, \mathrm{n}=2,10 \min , 97 \%$; 63d R $\mathrm{R}^{1}=$ Benzil, $\mathrm{n}=2,25 \mathrm{~min}, 91 \%$;

63e $\mathrm{R}^{1}=2$-Naphthyl, $\mathrm{n}=2$, 20min, $90 \%$; 64a $\mathrm{R}^{1}=\mathrm{C}_{6} \mathrm{H}_{5}, \mathrm{n}=1,15 \mathrm{~min}, 95 \%$;

64b $\mathrm{R}^{1}=2$-Naphthyl, $\mathrm{n}=1,20 \mathrm{~min}, 90 \% ; \mathbf{6 4 c} \mathrm{R}^{1}=4-\mathrm{MeC}_{6} \mathrm{H}_{4}, \mathrm{n}=1,10 \mathrm{~min}, 94 \%$;

66a $\mathrm{R}^{1}=\mathrm{R}^{2}=\mathrm{C}_{6} \mathrm{H}_{5}, 15 \mathrm{~min}, 95 \%$; 66 $\mathrm{R}^{1}=4-\mathrm{MeC}_{6} \mathrm{H}_{4}, \mathrm{R}^{2}=\mathrm{C}_{6} \mathrm{H}_{5}, 10 \mathrm{~min}, 92 \%$;

66c $\mathrm{R}^{1}=4-\mathrm{MeC}_{6} \mathrm{H}_{4}, \mathrm{R}^{2}=$ Methyl, 20 min, $92 \%$; 66d $\mathrm{R}^{1}=4-\mathrm{MeC}_{6} \mathrm{H}_{4}, \mathrm{R}^{2}=$ Sthiryl, 25 min, 89\%.

\section{Scheme 25}

The reaction has the character of universality: the reaction time and the yield of products practically do not depend on the nature of enones and aromatic thiols.

Ionic liquids can also be used in various condensation reactions, as both catalysts and solvents [2-20, 81].

It is known, that the Diels-Alder reaction is useful for the preparing of cyclic compounds from the corresponding unsaturated substances under mild conditions, even in the absence of a catalyst.

Diene 67 reacts rapidly with quinones $68 \mathbf{a}$ in the presence of ionic liquids to give cyclic compound 69a (scheme 26) [127].<smiles>CC(C)C1=CCC2C(=C1)CCC1C2(C)CCC[C@]1(C)C(=O)O</smiles>

67<smiles>[R]C1=CC(=O)C=CC1=O</smiles>

68a $\mathrm{R}^{1}=\mathrm{H}$

$68 \mathrm{bR}^{1}=\mathrm{Cl}$

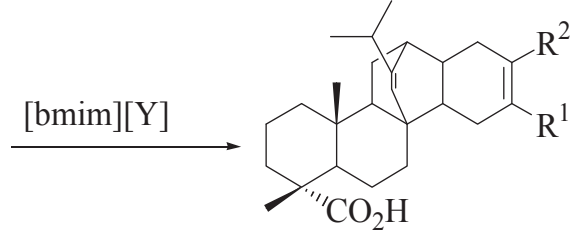

69a,b

Scheme 26

Table 2

Reaction time and product yield of the reaction 67 with $n$-benzoquinone $68 \mathrm{a}$

\begin{tabular}{cccc}
\hline Catalyst & Solvent & Reaction time, h & Yield, \% \\
\hline$[\mathrm{bmim}]\left[\mathrm{PF}_{6}\right] \mathbf{3 0 b}$ & $\mathrm{C}_{6} \mathrm{H}_{6}+\mathrm{C}_{6} \mathrm{H}_{14}$ & 1 & 100 \\
\hline$[\mathrm{bmim}]\left[\mathrm{BF}_{4}\right] \mathbf{3 0 a}$ & $\mathrm{C}_{6} \mathrm{H}_{6}+\mathrm{C}_{6} \mathrm{H}_{14}$ & 3.5 & 54 \\
\hline$[\mathrm{bmim}]\left[\mathrm{CF}_{3} \mathrm{CO}_{2}\right]$ & $\mathrm{C}_{6} \mathrm{H}_{6}+\mathrm{C}_{6} \mathrm{H}_{14}$ & 4 & 87 \\
\hline
\end{tabular}

As can be seen from table 2, the most effective catalyst in the synthesis is a mixture of [bmim] $\left[\mathrm{PF}_{6}\right]$-benzenehexane. 
The authors performed the reaction of the diene 67 with 2-chloro- $p$-benzoquinone $\mathbf{6 8 b}$ using catalytic quantities of $[\mathrm{bmim}]\left[\mathrm{PF}_{6}\right],[\mathrm{bmim}]\left[\mathrm{BF}_{4}\right]$ or $[\mathrm{bmim}]\left[\mathrm{CF}_{3} \mathrm{CO}_{2}\right]$ (see table 3$)$.

Reaction time and product yield of the reaction 67 with 2-chloro- $p$-benzoquinone $68 \mathrm{a}$

\begin{tabular}{cccc}
\hline Catalyst & Solvent & Reaction time, h & Yield, \% \\
\hline$[\mathrm{bmim}]\left[\mathrm{PF}_{6}\right] \mathbf{3 0 b}$ & $\mathrm{CH}_{2} \mathrm{Cl}_{2}+\mathrm{C}_{6} \mathrm{H}_{14}$ & 3 & 100 \\
\hline$[\mathrm{bmim}]\left[\mathrm{BF}_{4}\right] \mathbf{3 0 a}$ & $\mathrm{CH}_{2} \mathrm{Cl}_{2}+\mathrm{C}_{6} \mathrm{H}_{14}$ & 6 & 90 \\
\hline$[\mathrm{bmim}]\left[\mathrm{CF}_{3} \mathrm{CO}_{2}\right]$ & $\mathrm{CH}_{2} \mathrm{Cl}_{2}+\mathrm{C}_{6} \mathrm{H}_{14}$ & 20 & 75 \\
\hline
\end{tabular}

The Diels-Alder reaction has been performed regioselectively. The major product is the compound $69 \mathrm{~b}\left(\mathrm{R}^{1}=\mathrm{Cl}\right.$, $\left.\mathrm{R}^{2}=\mathrm{H}\right)$.

The allylic oxidation of the lactone $\mathbf{7 0}$ (scheme 27) has also been investigated [128].

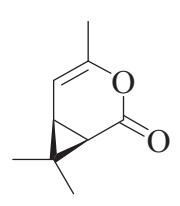

70

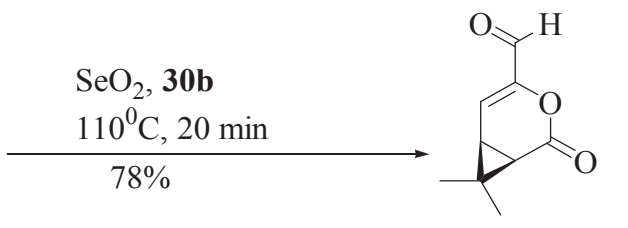

$71 \mathrm{a}$<smiles>CC1(C)C2C=C(CO)OC(=O)C21</smiles>

$71 b$

\section{Scheme 27}

It was shown that increasing the amount of $\mathrm{SeO}_{2}$ up to a 3 eq. and carrying out the reaction in the ionic liquid $\mathbf{3 0 b}$ leads to a single product 71a.

When compound 70 is heated with $\mathrm{SeO}_{2}$ in ionic liquids at $50^{\circ} \mathrm{C}$, the product is the mixture $71 \mathbf{a}, \mathbf{b}$ (total yield $60 \%)$.

Aldehydes are obtained by the hydroformylation of olefins on $\mathrm{Rh}, \mathrm{Pt}, \mathrm{Co}$, or Ru-catalysts, which are quite expensive. However, acetylacetonic and carbonylic metal complexes dissolved in imidazole with the hexafluorophosphate as the anion showed high activity and selectivity in obtaining products of hydroformylation [31,32]. Metal containing ionic liquids were proposed for the hydroformylation of the $\beta$-keto ether 72 [32].

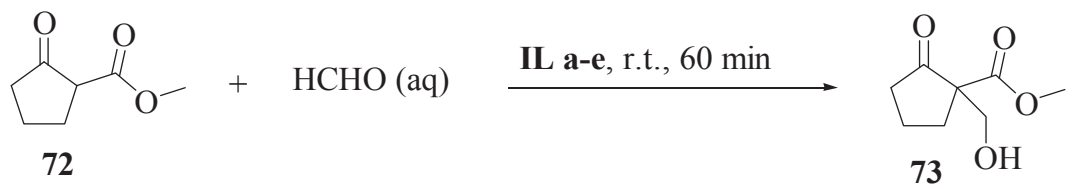

IL : a $[\mathrm{bmim}]\left[\mathrm{FeCl}_{4}\right], 90 \%$; b $[\mathrm{bmim}]\left[\mathrm{NiCl}_{4}\right], 77 \%$; c $[\mathrm{bmim}]\left[\mathrm{CoCl}_{4}\right], 76 \%$; d $[$ bmim $]\left[\mathrm{CuCl}_{4}\right], 44 \%$; e $[\mathrm{bmim}]\left[\mathrm{TiCl}_{5}\right], 32 \%$.

Scheme 28

A convenient method of preparing hydroxy derivative $\mathbf{7 3}$ consists in the treatment of compound $\mathbf{7 2}$ with system -aqueous formaldehyde $/ 0.1 \mathrm{~mol}-\%$ of $[\mathrm{bmim}]\left[\mathrm{FeCl}_{4}\right]$. The utilization of titanium tetrachloride decreased the yield of the product 73 (scheme 28).

We also began by designing solvents/catalysts which would be prepared from imidazole 74 (scheme 29). 


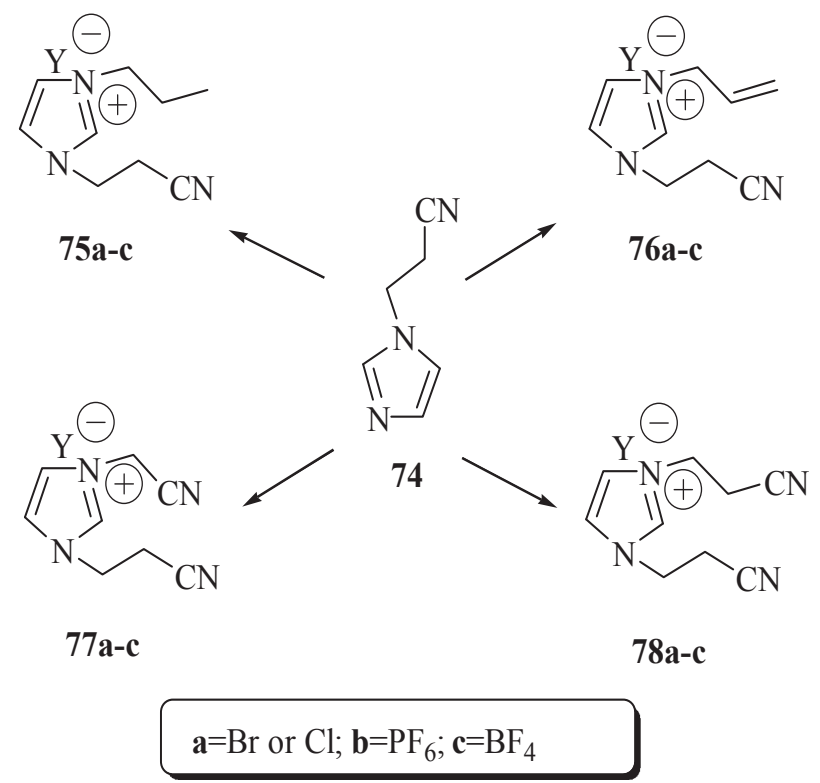

Scheme 29

The imidazolium salts 75a,76a,77a, 78a $(\mathrm{Y}=\mathrm{Br}$ or $\mathrm{Cl}$ ), which can be prepared by the treatment of imidazole $\mathbf{7 4}$ with alkyl halides, can be converted to ionic liquids $\mathbf{7 5 b}, \mathbf{7 6 b}, \mathbf{7 7 b}, \mathbf{7 8 b}$ as well as $\mathbf{7 5 c , 7 6 c , 7 7 c , 7 8 c ~ b y ~ t h e ~ t r e a t m e n t ~ w i t h ~}$ inorganic salt $\left(\mathrm{NaBF}_{4}\right.$ or $\left.\mathrm{KPF}_{6}\right)$ [61-67].

Olefins can be acylated or hydroxyformylated with an acyl halide or paraformaldehyde and Lewis-acid catalyst [130-141].

We have previously seen that $(+)-3$-carene 79 can be acylated in the position 4 in the presence of compound $75 \mathbf{c}$ (scheme 30) [137,138].

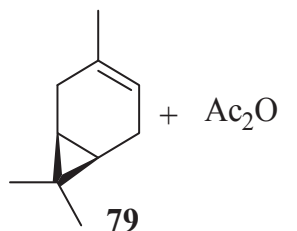

79

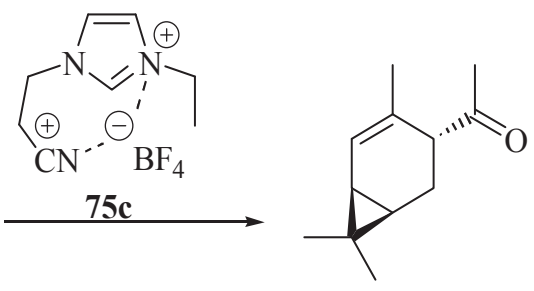

80

Scheme 30

The catalytic action of the synthesized imidazolium salts is probably linked to the initial formation of the acylcation from $\mathrm{Ac}_{2} \mathrm{O}$ with the participation of the bipolar particle $-\mathrm{CH}_{2} \mathrm{C}^{+}=\mathrm{N}^{-\cdots \mathrm{BF}_{4}^{-}}$.

Compound 79 can be also acylated by the treatment with mixture $\mathrm{Ac}_{2} \mathrm{O} / \mathbf{7 5 a}$ or $\mathrm{Ac}_{2} \mathrm{O} / \mathbf{7 5 b}$ to give target $\mathbf{8 0 a}, \mathbf{b}$ (table 4).

The reaction conditions and product 80 yield

\begin{tabular}{cccc}
\hline Ionic liquid & Quantity of IL & Yield, $\%$ & Reaction time, $\mathbf{h}$ \\
\hline $\mathbf{7 5 a}$ & $6 \mathrm{~mol} \%$ & 33 & 49 \\
\hline $\mathbf{7 5 a}$ & $200 \%$ & 37 & 25 \\
\hline $\mathbf{7 5 b}$ & $6 \mathrm{~mol} \%$ & 29 & 48 \\
\hline $\mathbf{7 5 c}$ & $6 \mathrm{~mol} \%$ & 38 & 46 \\
\hline
\end{tabular}

Since $(+)-3$-carene $\mathbf{7 9}$ is converted to ketone $\mathbf{8 0}$, this is also a method for the preparing of 4-substituted 2-carenes 81, 82 (scheme 31). 


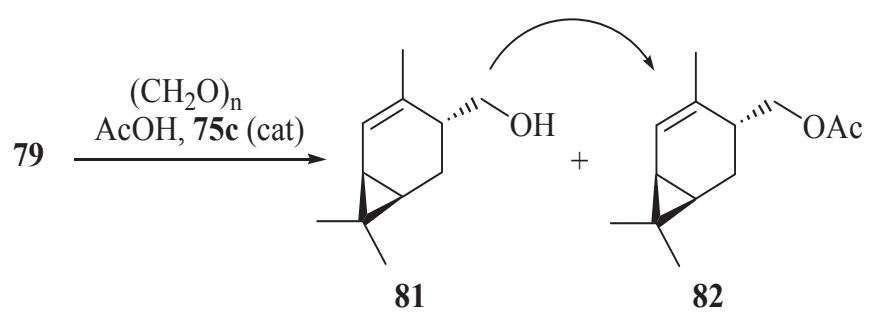

Scheme 31

The presence of a free carboxymethyl group in the imidazole molecule may enhance the hydrophility of substances and therefore broaden the area of their utilization [139-141]. Due to this, investigations connected to the search of novel carboxy-functionalized ionic liquids and to the elaboration of effective catalysts on their basis, are promising and present practical interest.

Carboxymethyl group can be introduced by the treatment of $\mathrm{N}$-methyl imidazole $83(\mathrm{R}=\mathrm{Me})$ with monochloroacetic acid in acetonitrile (scheme 32) [56-59].<smiles>[R]n1ccnc1</smiles>

74,83<smiles>O=C(O)CCl</smiles><smiles>CCCC</smiles>

$84 a, b$<smiles></smiles>
(1)<smiles>[R]N1CCN(C(=O)CCl)C1</smiles>

$85 a, b \quad O$

$$
\mathbf{a}: \mathrm{R}=\mathrm{Me} ; \mathbf{b}: \mathrm{R}=\mathrm{CH}_{2} \mathrm{CH}_{2} \mathrm{CN} \text {. }
$$

\section{Scheme 32}

The mixture $\mathbf{8 4 a , 8 5 a}$ is presented as oil-like liquid.

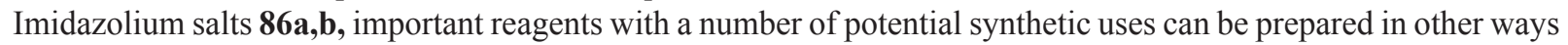
(scheme 33).

When imidazole 83 is treated with tert-butyl 2-bromoacetate, quaternization that is analogous to scheme 32 occurs. Deprotection gives a free carboxy- group of substance 86a. A particularly mild method for the conversion of salt 86a to imidazolium salt 86b uses $\mathrm{H}_{2} \mathrm{SO}_{4}$ (scheme 33).

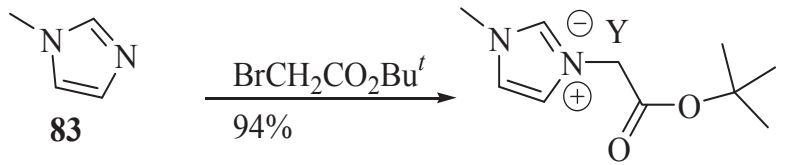

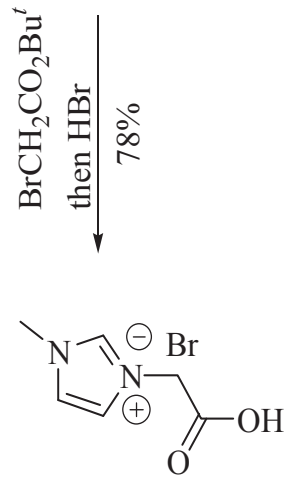

$86 a$



86b

Scheme 33

3,4-Dihydropyrimidine-2(1H)-ones(thiones) 87a,b-92a,b can be synthesized via one-pot reaction of ureas (thioureas), aldehydes with $\beta$-dicarbonyl compounds catalyzed by ionic liquids (scheme 34) [121,142]. 


$$
\begin{aligned}
& \text { 87: } \mathrm{Ar}=\mathrm{Ph}, \mathrm{X}=\mathrm{O}(\mathrm{a}), \mathrm{S}(\mathrm{b}) ; \mathbf{8 8}: \mathrm{Ar}=3,4-(\mathrm{MeO})_{2} \mathrm{C}_{6} \mathrm{H}_{3}, \mathrm{X}=\mathrm{O}(\mathrm{a}), \mathrm{S}(\mathrm{b}) ; \\
& \mathbf{8 9}: \mathrm{Ar}=2,4-(\mathrm{MeO})_{2} \mathrm{C}_{6} \mathrm{H}_{3}, \mathrm{X}=\mathrm{O}(\mathrm{a}), \mathrm{S}(\mathrm{b}) ; \mathbf{9 0}: \mathrm{Ar}=2,4-\mathrm{Cl}_{2} \mathrm{C}_{6} \mathrm{H}_{3}, \mathrm{X}=\mathrm{O}(\mathrm{a}), \mathrm{S}(\mathrm{b}) ; \\
& \mathbf{9 1}: \mathrm{Ar}=4-\mathrm{MeOC}_{6} \mathrm{H}_{4}, \mathrm{X}=\mathrm{O}(\mathrm{a}), \mathrm{S}(\mathrm{b}) ; \mathbf{9 2}: \mathrm{Ar}=4-\left(\mathrm{Me}_{2} \mathrm{~N}\right) \mathrm{C}_{6} \mathrm{H}_{4}, \mathrm{X}=\mathrm{O} \text { (a), } \mathrm{S}(\mathrm{b}) .
\end{aligned}
$$

\section{Scheme 34}

It was established that using ionic liquids as organocatalysts of Biginelli reaction leads to the decrease of the reaction time and the increase of the product yields, as compared to the activity of other ionic liquids. It should be noted that in most cases, the yields of the 3,4-dihydropyrimidine-2(1H)-thiones are higher than those of their oxygencontaining analogues.

Considerable attention has recently been focused on the conversion of the simple starting materials into highly functionalized products such as $\alpha$-hydroxy- or $\alpha$-amino-alkyl activated olefins [1-6]. The 2-(3-hydroxy-2-oxo-2,3dihydro- $1 H$-indolyl)acrylates sequence plays a very important part in organic as well as medicinal chemistry $[143,144]$. We established, that the two-component system consisting of ionic liquid and dimethylaminopyridine (1:8) is an efficient catalyst for obtaining 2-(3-hydroxy-2-oxo-2,3-dihydro-1H-3-indolyl)acrylates 94a-h (scheme 35)[145-147].<smiles>[R]c1ccc2c(c1)C(=O)C(=O)N2[R]</smiles>

93a-h

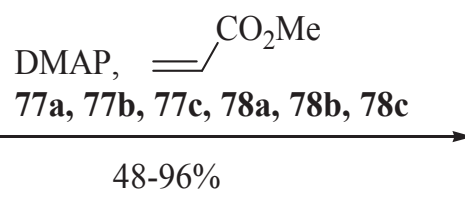

77a, 77b, 77c, 78a, 78b, 78c

$48-96 \%$<smiles>[R]C(=C)C1(O)C(=O)N([R])c2ccc([R])cc21</smiles>

94a-h
a) $\mathrm{R}^{1}=\mathrm{H}, \mathrm{R}^{2}=-\mathrm{Et}$; b) $\left.\mathrm{R}^{1}=\mathrm{H}, \mathrm{R}^{2}=-\mathrm{C}_{3} \mathrm{H}_{7} ; \mathbf{c}\right) \mathrm{R}^{1}=\mathrm{H}, \mathrm{R}^{2}=-\mathrm{CH}_{2} \mathrm{CH}=\mathrm{CCl}-\mathrm{Me}$;
d) $\left.\mathrm{R}^{1}=\mathrm{H}, \mathrm{R}^{2}=-\mathrm{CH}_{2}-\mathrm{CH}=\mathrm{CH}_{2} ; \mathbf{e}\right) \mathrm{R}^{1}=-\mathrm{Me}, \mathrm{R}^{2}=-\mathrm{CH}_{2}-\mathrm{CH}=\mathrm{CH}_{2}$;
f) $\mathrm{R}^{1}=\mathrm{H}, \mathrm{R}^{2}=-\mathrm{CH}_{2}-\mathrm{CCH} ;$ g) $\left.\mathrm{R}^{1}=\mathrm{H}, \mathrm{R}^{2}=-\mathrm{CH}_{2}-\mathrm{C}_{6} \mathrm{H}_{5} ; \mathbf{h}\right) \mathrm{R}^{1}=\mathrm{H}, \mathrm{R}^{2}=-\mathrm{C}_{4} \mathrm{H}_{9}$

\section{Scheme 35}

The reaction was performed under stirring during 1 hour at room temperature of the mixture of isatines 93a-h: methyl acrylate : dimethylaminopyridine : ionic liquid at a molar ratio of $1: 1.56: 0.5: 0.06$.

To conclude, it should be noted that due to the diversity and specificity of their characteristics, ionic liquids proved to be very attractive for catalysis and organic synthesis.

\section{Conclusion}

Up to date, low-temperature melting imidazole salts or ionic liquids were determined to be useful as alternative solvents, catalytic media and simply catalysts in various processes of organic synthesis.

In this paper we reviewed the available literature and our own data on the synthesis, physical and chemical properties, and future uses of imidazolic ionic liquids in such reactions as esterification, alkylation, epoxidation, acylation, isomerization, cycloaddition, etc. Ionic liquids form a two-phase system, which greatly facilitates the separation of products from the catalyst. In addition, they can be used repeatedly without any activity loss and without a need of regeneration. Another important advantage is represented by the strength (for some systems - superacidic) of metallochlorinated ionic liquids, a property that allows for the transformation process to occur at low temperatures. These properties permit ionic liquids to be full participants in "alternative" chemical processes, even if we don't take into account the productivity and selectivity gains presented in this review. 
We consider that electrochemical studies (using electrolytes of solar batteries, and so on.), electrocatalysis and complex metallic catalysis represent promising areas of further research for those interested.

\section{Acknowledgements}

D. Prodius thanks the Alexander von Humboldt Foundation for financial support.

\section{References}

[1]. Bellina, F; Cauteruccio, S.; Rossi, R. Tetrahedron. 2007, 63, 4571-4624.

[2]. Eds. Wasserscheid, P.; Welton, T. Ionic Liquids in Synthesis, Weinheim: Wiley-VCH Verlag, 2002,364 p.

[3]. Welton, T. Chem. Rev. 1999, 99, 2071-2083.

[4]. Dupont, J.; De Souza, R.F.; Suarez, P.A. Chem. Rev. 2002, 102, 3666-3692.

[5]. Baudequin, C.; Baudoux, J.; Levillain, J.; Cahard, D.; Gaumont, A.C.; Plaquevent, J.C. Tetrahedron. 2003, 14, 3081-3093.

[6]. Davis, J.H. Chem.Lett. 2004, 33, 1072-1077.

[7]. Kustov L.M; Vasinat V.; Ksenofontov V.A. Rus.Chem.J. 2004, 6, 13-35.

[8]. Braunstein P. J.Organometal. Chem. 2004, 689, 3953-3967.

[9]. Jain, N.J.; Kumar, A.; Chauhan, S.; Chauhan, S.M.S. Tetrahedron. 2005, 61, 1015-1060.

[10]. Lin, I.J.B.; Vasam, C.S. J.Organometal. Chem. 2005, 690, 3498-3512.

[11]. Ranke, J.; Stolte, S.; Stormann, R.; Arning, J.; Jastorff, B. Chem. Rev. 2007, 107, 2118-2206.

[12]. Chowdhury, S.; Mohan, R.S.; Scott, J.L. Tetrahedron. 2005, 63, 2363-2389.

[13]. Binnemans, K. Chem. Rev. 2007, 107, 2592-2614.

[14]. Parvulescu, V.I.; Hardacre, C. Chem. Rev. 2007, 107, 2661-2665.

[15]. Greaves, T.L.; Drummond, C.J. Chem. Rev. 2008, 108, 206-237.

[16]. Lei, Z.; Chen, B.; Li, C.; Liu, H. Chem. Rev. 2008, 108, 1419-1455.

[17]. Haumann, M.; Riisager, A. Chem. Rev. 2008, 108, 1474-1497.

[18]. Martins, M. A. P.; Frizzo, C.P.; Moreira, D.N.; Zanatta, N.; Bonacorso, H.G. Chem. Rev. 2008, 108, $2015-2050$.

[19]. Hapiot, P.; Lagrost, C. Chem. Rev. 2008, 108, 2238-2264.

[20]. Plaquevent, J.C.; Levillain, J.; Guillen, F.; Malhiac, C.; Gaumont, A.C. Chem. Rev. 2008, 108, 5035-5060.

[21]. Dupont, J.; Consorti, C.S.; Suarez, P.A.Z.; De Souza, R. Org. Synthesis. 2002, 79, 236-243.

[22]. Mu, Z.; Liu, W.; Zhang, S.; Zhou, F. Chem. Lett. 2004,33, 524-525.

[23]. Bonhote, P.; Dias, A.P.; Papageorgiou, N.; Kalyanasundaram, K.; Gratzel, M. Inorg. Chem. 1996, 35, 11681178.

[24]. Lin, Y.S.; Lin, C.Y.; Liu, C.W.; Tsai, T.Y.R. Tetrahedron.2006, 62, 872-877.

[25]. Suarez, P.A.Z.; Dullius, J.E.L.; Einloft, S.; De Souza, R.; Dupont, J. Polyhedron. 1996, 15, 1217-1219.

[26]. Lee, J.K.; Kim, M.J. J.Org.Chem. 2002, 67, 6845-6847.

[27]. Pernak, J.; Czepukowich, A. Ind.Eng.Chem.Res. 2001, 40, 2379-2383.

[28]. Howarth, J.; Hanlon, K.,; Fayne, D.; Mccorma, P. Tetrahedron Lett. 1997, 38, 3097-3100.

[29]. Bolm, C.; Legros, J.; Le Paih, J.; Zani, L. Chem. Rev. 2004, 104, 6217-6254.

[30]. Putilova E.S.; Krishtal G.N.; Jdankina G.M.; Troitskii N.A.; Zvotin S.G. Russ.J.Org.Chem. 2005, 41, 524-528.

[31]. Haumann, M.; Riisager, A. Chem. Rev., 2008, 108, 1474-1497.

[32]. Bica, K.; Gaertner, P. Eur. J. Org. Chem. 2008,14, 3453-3456.

[33]. Lall, S.I.; Mancheno, D.; Castro, S.; Behaj, V.; Lee, J.; Cohen, I.; Engel, R. Chem. Commun., 2000, 24, 24132414.

[34]. Marcus, Y. Chem. Rev. 2004, 104, 3405-3452.

[35]. Arora, P.; Zhang, Z. Chem. Rev., 2004, 104, 4419-4462.

[36]. Holbrey, J. D.; M.Reichert, W.; Swatloski, R.P.; Broker, G.A.; Pitner, W.R.; Seddon, K.R.; Rogers, R.D. Green Chem., 2002, 4, 407-413.

[37]. Abbott, A.P.; Capper, G.; Davies, D.L.; Munro, H.L.; Rasheed, R.K.; Tambyrajah, V. Chem. Commun., 2001, 19, 2010-2011.

[38]. Namboodiri, V.V.; Varma, R.S. Tetrahedron Lett., 2002, 43, 5381-5383.

[39]. Leveque, J.M.; Luche, J.L.; Petrier, C.; Roux, R.; Bonrath, W. Green Chem., 2002, 4, 357-360.

[40]. Varma, R.S.; Namboodiri, V.V. Chem. Commun., 2001, 7, 643-644.

[41]. Wasserscheid, P.; Driessen-Hölscher, B.; Van Hal, R.; Steffens, H.C.; Zimmermann, J. Chem. Commun., 2003, 16, 2038-2039.

[42]. Itoh, H.; Naka, K.; Chujo, Y. J. Am. Chem. Soc., 2004, 126, 3026-3027.

[43]. Hagiwara, R.; Ito, Y. J. Fluor. Chem. 2000, 105, 221-227.

[44]. Holbrey, J.D.; Turner, M.B.; Reichert, W.M.; Rogers, R.D. Green Chem., 2003, 6, 731-736.

[45]. Bosmann, A.; Schulz, P.; Wasserscheid, P. Monatshefte fur Chimie. 2007, 138, 1159-1161. 
[46]. Gu, Y.; Shi, F.; Deng, Y. J. Mol.Catal. A: Chem. 2004, 212, 71-75.

[47]. Gholap, A.R.; Venkatesan, K.; Daniel, T.; Lahoti, R.J.; Srinivasan, K.V. Green Chem., 2004, 3,147-150.

[48]. Qiao, K.; Yokoyama, C. Chem. Lett. 2004, 33, 472-473.

[49]. Zhao, D.; Fei, Z.; Scopelliti, R.; Dyson, P.J. Inorg. Chem. 2004, 43, 2197-2205.

[50]. Fei, Z.; Zhao, D.; Geldbach, T.J.; Scopelliti, R.; Dyson, P.J. Chem.Eur.J. 2004, 10, 4886-4893.

[51]. Fei, Z.; Zhao, D.; Geldbach, T.J.; Scopelliti, R.; Dyson, P.J.; Antonijevic, S.; Bodenhausen, G. Angew. Chem. Int. Ed. 2005, 44, 5720-5725.

[52]. Ranu, B.C.; Banerjee, S. J.Org. Chem. 2005, 70, 4517-4519.

[53]. Zhao, G.; Jiang, T.; Gao, H.; Han, B.; Huang, J.; Sun, D. Green Chem., 2004, 2, 75-77.

[54]. Cole, A.C.; Jensen, J.L.; Ntai, I.; Tran, K.L.T.; Weaver, K.J.; Forbes, D.C.; Davis, J.H. J. Am. Chem. Soc., 2002, 124, 5962-5963.

[55]. Wang, Z.; Wang, C.; Bao, W.; Ying, T. J. Chem. Research. 2005, 6, 388-390.

[56]. Macaev, F.; Stingaci, E.; Munteanu, V. Soil Chemical Pollution, Risk Assesment, Remediation and Security; Springer Science+Business: Media B.V., 2008, 223-228.

[57]. Macaev, F.; Stingaci, E.; Munteanu, V.; Pogrebnoi S.I. II International conference "Chemistry, structure and function of bimolecules" Minsk, 2006, PR-88.

[58]. Macaev, F.; Stingaci, E.; Munteanu, V.; Pogrebnoi S.I. ; Ribkovskaia, Z.; Barba, A. Russ. J. Org. Chem., 2007, 43, 1518-1520.

[59]. Şargorovschi, V.; Styngach, E.; Macaev, F. Chem. J. Mold., 2008, 3, 95-97.

[60]. Zaderenko, P.; Gil, M.S.; Ballesteros, P.; Cerdan, S. J. Org. Chem., 1994, 59, 6268-6273.

[61]. Munteanu, V.A. Conferinta Internațională a Tinerilor Cercetatori. Chişinău, 2005, 66.

[62]. Munteanu, V.A. Conferinta Internațională a Tinerilor Cercetatori. Chişinău, 2005, 65.

[63]. Munteanu, V.; Stingaci, E.; Macaev, F. All Russian scientific colloquium together with young scientific workshop. Russia, Ufa, 2007, 117.

[64]. Macaev, F.Z.; Stingaci, E.P.; Munteanu, V. $4^{\text {th }}$ Euroasian Meeting on Heterocyclic Chemistry. Thessaloniki, Greece, 2006, 269-270.

[65]. Macaev, F.; Stingaci, E.; Munteanu, V. International Symposium on Advanced Science in Organic Chemistry. Sudak, Ucraine. 2006, C-102.

[66]. Macaev, F.; Munteanu, V.; Stingaci, E.; Barba, A.; Pogrebnoi, S. Chem.J.Moldova. 2007, 2, 119-122.

[67]. Munteanu, V.; Stingaci, E.; Pogrebnoi, S.; Barba, A.; Macaev, F. The II ${ }^{\text {nd }}$ International Conference of the Chemical Society of the Republic of Moldova "Achievements and Perspectives of Modern Chemistry". Chisinau, Moldova, 2007, 131.

[68]. Horvath, A. Synthesis.1994, 1, 102-106.

[69]. Fei,Z.; Zhao, D.; Pieraccini, D.;Ang, W.H.; Geldbach, T.J.; Scopelliti, R.; Chiappe, C.; Dyson, P.J. Organometallics. 2007, 26, 1588-1598.

[70]. Bates, E.D.; Mayton, R.D.; Ntai, I.; Davis, J.H. J. Am. Chem. Soc., 2002, 124, 926-927.

[71]. Demberelnyamba, D.; Yoon, S.J.; Lee, H. Chem. Lett. 2004, 33, 560-651.

[72]. Li, P.; Wang, L.; Wang, M.; Zhang, Y. Eur. J. Org. Chem. 2008, 1157-1160.

[73]. Tsarevsky, N.V.; Matyjaszewski, K. Chem. Rev. 2007, 107, 2270-2299.

[74]. Trindade, A.F.; Gois, P.M.P.; Afonso, C.A.M. Chem. Rev., 2009, 109, 418-514.

[75]. Ikegami, S.; Hamamoto, H. Chem. Rev., 2009, 109, 583-593.

[76]. Minakata, S.; Komatsu, M. Chem. Rev. 2009, 109, 711-724.

[77]. Toma, S.; Meciarova, M.; Sebesta, R. Eur. J. Org. Chem. 2009, 321-327.

[78]. Gu, Y.; Karam, A.; Jerome, F.; Barrault. J. Org.Lett. 2007, 9, 3145-3148.

[79]. Kucherenko, A.S.; Struchkova, M.I.; Zlotin, S.G.. Eur. J. Org. Chem. 2006, 2000-2004.

[80]. Slotin, S.G.; Kucherenko, A.S.; Mendeleev. Commun. 2007, 17, 20.

[81]. Zhao, D.; Wu, M.; Kou, Y.; Min, E. Catalysis Today, 2002, 74, 157-189.

[82]. Boon, J.A.; Levisky, J.A.; Pflug, J.L.; Wilkes, J.S. J. Org. Chem., 1986, 51, 480-483.

[83]. Stark, A.; Maclean, B.L.; Singer, R.D. J. Chem. Soc., Dalton Trans., 1999, 63-66.

[84]. Song, C. E.; Roh, E. J.; Shim, W. H.; Choi, J.H. Chem. Commun., 2000, 17, 1695-1696.

[85]. Surette, J.K.D.; Green, L.; Singer, R.D. Chem. Commun., 1996, 24, 2753-2754.

[86]. Ellis, B.; Hubert, F.; Wassersccheid, P. Patent WO № 00/41809, 2000.

[87]. Abdul-Sada, A.; Atkins, M.P.; Ellis, B.; Kenneth, P.; Hodgson, G.; Morgan, M.L.M.; Seddon, K.R. Patent US № 5994602, 1999.

[88]. Sherif, F.G.; Shyu, L.J.; Greco, C.; Talma, A.G.; Lacroix, C.P.M. Patent WO № 98/03454, 1998.

[89]. Abdul-Sada, A.; Atkins, M.P.; Ellis, B.; Kenneth, P.; Hodgson, G.; Morgan, M.L.M.; Seddon, K.R. Patent WO № 95/21809, 1995.

[90]. Earle, M.J.; Katdare, S.P.; Seddon, K.R. Organic Lett. 2004, 6, 707-710. 
[91]. Earle, M.J.; Mccormac, P.B.; Seddon, K.R. Chem. Commun., 1998, 20, 2245-2246.

[92]. Hao-Yu, Shen; Zaher, M.A. Judeh; Chi Bun, Ching. Tetrahedron Lett., 2003, 27, 981-983.

[93]. Boovanahalli, S.K.; Kim, D.W.; Chi, D.Y. J.Org.Chem. 2004, 69, 3340-3344.

[94]. Youquan, Deng; Feng, Shi; Jiajian, Beng; Kun, Qiao. J. Mol. Catal. A, Chem. 2001, 165, 33-36.

[95]. Zhao, H.; Malhotra, S.V. In: Catalysts of Organic Reactions. Ed. D. Morrell. New York: Marcel Dekker, 2002, 83, 667.

[96]. Hua-Ping, Zhu; Fan, Yang; Jie, Tang; Ming-Yuan, He. Green Chem., 2003, 5, 38-39.

[97]. Liu, Z.; Chen, Z.C.; Zheng, Q.G. Org. Lett. 2003, 5, 3321-3323.

[98]. Yadav, J.S.; Reddy, B.V.S.; Basak, A.K.; Narsaiah, A.V. Chem. Lett. 2004, 33, 248-249.

[99]. Chauvin, Y.; Einloft, S.; Olivier, H. Ind. Eng. Chem. Res., 1995, 34, 1149-1155.

[100]. Olivier, H.; Laurent-Gerot, P. J. Mol. Catal. A, Chem. 1999, 148, 43-48.

[101]. Wasserscheid, P.; Hilgers, C.; Gordon, C.M., Muldoon, M.J.; Dunkin, I.R. Chem. Commun., 2001, 13, 11861187.

[102]. Ellis, B.; Keim, W.; Wasserscheid, P. Chem. Commun., 1999, 4, 337-338.

[103]. Mastrorilli, P.; Nobile, C.F.; Gallo, V.; Suranna, G.P.; Farinola, G. J. Mol. Catal. A, Chem. 2002, $184,73-78$.

[104]. Ambler, P.W.; Hodgson, P.K.G.; Stewart, N.J. Patent US № 5304615, 1994.

[105]. Chauvin, Y.; Einloft, S.; Oliver, H. Patent US № 5502018, 1996.

[106]. Abdul-Sada, A.; Ambler, P.W.; Hodgson, P.K.G.; Seddon, K.R.; Stewart, N.J. Patent WO № 95/21871, 1995.

[107]. Wassescheid, P.; Keim, W. Patent WO № 98/47616, 1998.

[108]. Chauvin, Y.; Einloft, S.; Oliver, H. Patent US № 5550304, 1996.

[109]. Vallee, C.; Valerio, C.; Chauvin, Y.; Niccolai, G.P.; Basset, J.M.; Santini, C.C.; Galland, J.C.; Didillon, B. J. Mol. Catal. A, Chem. 2004, 214, 71-81.

[110]. Pelrine, B.P.; Comolli, A.G.; Lee, L.K. Patent US № 6139723, 2000.

[111]. Murphy, V Patent WO № 00/32658, 2000.

[112]. Adams, C.J.; Earle, M.J.; Seddon, K.R. Green Chem., 2000, 2, 21-24.

[113]. Green, K.J.; Dera, H.G.H.; Barnes, P.N.; Lever, N.D.J.; Grant, K.A. Patent WO № 00/40673, 2000.

[114]. Mi, X.; Luo, S.; Cheng, J.PJ.Org.Chem. 2005, 70, 2338-2341.

[115]. Mi, X.; Luo, S.; Xu, H.; Zhang, L., Cheng, J.P. Tetrahedron. 2006, 62, 2537-2544.

[116]. Lin, Y.S.; Lin, C.Y.; Liu, C.W.; Tsai, T.Y.R. Tetrahedron. 2006, 62, 872-877.

[117]. Grin'ko, M.; Kulchitskii, V.; Ungur, N.; Vlad, P.F. Chem. Natur. Comps. 2006, 42, 439-441.

[118]. Kamal, A.; Chouhan, G. Tetrahedron Lett. 2005, 46, 1489-1491.

[119]. Hakkou, H.; Eynde, J.J.V; Hamelin, J.; Bazureau, J.P. Tetrahedron. 2004, 60, 3745-3753.

[120]. Legeay, J.C; Eynde, J.J.V; Bazureau, J.P. Tetrahedron. 2008, 64, 5328-5335.

[121]. Peng, J.; Deng, Y. Tetrahedron Lett. 2001, 42, 5917-5919.

[122]. Yadav, J.S.; Reddy, B.V.S.; Basak, A.K.; Narsaiah, A.V. Chemistry Lett. 2004, 33, 248-249.

[123]. Tohg, K.H.; Wong, K.Y.; Chan, T.H. Organic Lett. 2003, 5, 3423-3425.

[124]. Chandrasekhar, S.; Narasihmulu, C.; Jagadeshwar, V.; Reddy, K.V. Tetrahedron Lett. 2003, 44, 3629-3630.

[125]. Yadav, J.S.; Reddy, B.V.S.; Reddy, C.S.; Bajasekhar, K. J.Org.Chem. 2003, 68, 2525-2527.

[126]. Yadav, J.S.; Reddy, B.V.S.; Gakul, B. J.Org.Chem. 2003, 68, 7098-7100.

[127]. Fazliev R.R.; Vafina G.F.; Galin F.Z. Vestnik BGU, 2008, 13, 38.

[128]. Fasradze V.G.; Kukovinets O.S.; Salimova E.V.; Giliazetdinova I.I.; Zvereva T.I.; Galin F.Z. XVIII Mendeleev Congress on Generaland Apllied Chemistry. Moscow, 2007, 1, 251.

[129]. Macaev F.Z. Russ.Chem.B1. 2000, 8, 1480-1481.

[130]. Macaev F.Z.; Galin F.Z.; Tolstikov G.A. Russ.Chem.B1. 1995, 3, 517-518.

[131]. Macaev F.Z.; Galin F.Z.; Tolstikov G.A. Russ.Chem.B1. 1995, 2, 305-309.

[132]. Tolstikov G.A.; Galin F.Z.; Macaev F.Z.; Ignatiuk V.N.; Sultanova V.S.; Davletov R.G. Russ.J.Org.Chem., 1990, 26, 1671-1678.

[133]. Tolstikov G.A.; Galin F.Z.; Macaev, F.Z.; Ignatiuk, V.N. Tetrahedron, 2006, 62, 9-29.

[134]. Macaev, F. Z.; Malkov, A. V. Tetrahedron, 2006, 62, 9-29.

[135]. Kropp, P.J.; Hecker, D.C.; Flant, T.J. Tetrahedron. 1968, 24, 1385-1395.

[136]. Ohloff, G.; Farnow, H.; Philipp, W. Liebigs Ann. Chem.-1958, 6132, 43-55.

[137]. Macaev, F.; Stingaci, E.; Munteanu, V. International conference on chemistry of nitrogen containing heterocycles. Kharkiv, Ucraine, 2006, 91.

[138]. Macaev, F.; Gavrilov, K.; Muntyanu, V.; Styngach, E.; Vlad, L.; Bets, L.; Pogrebnoi, S.; Barba, A. Chem. Natur. Comps. 2007, 43, 136-139.

[139]. Lin, I.J.B.; Vasam, C.S. J. Organomet. Chem., 2005, 690, 3498-3512.

[140]. Dallinger, D.; Kappe, C.O. Chem. Rev., 2007, 107, 2563-2591. 
[141]. Fei, Z.; Zhao, D.; Geldbach, T.J.; Scopelliti, R.; Dyson, P.J., Antonijevic, S.; Bodenhausen, G. Angew. Chem. Int. Ed. 2005, 44, 5720-5725.

[142]. Yadav, J.S.; Reddy, B.V.S.; Basak, A.K.; Narsaiah, A.V. Green Chem., 2003, 5, 60-63.

[143]. Yong, S. R.; Ung, A.T.; Pyne, S.G.; Skelton, B.W.; White, A.H. Tetrahedron. 2007, 63, 1191-1199.

[144]. Gartner, M.; Sunder-Plassmann, N.; Seiler, J.; Utz, M.; Vernos, I.; Surrey, T.; Giannis, A. Chem.Bio.Chem. 2005, 6, 1173-1177.

[145]. Sargorovschi, V., Iudin, T., Sucman, N.; Stingaci, E.; Macaev, F. The International Conference dedicated to the $50^{\text {th }}$ anniversary from the foundation of the Institute of Chemistry of the Academy of Science of Moldova". 2009, 211.

[146]. Sucman, N.; Sargorovschi, V.; Iudin, T.; Stingaci, E.; Radul, O.; Macaev, F. The International Conference dedicated to the 50th anniversary from the foundation of the Institute of Chemistry of the Academy of Science of Moldova". 2009, 157.

[147]. Sucman N.S.; Bets L.P.; Sargorovschi V.; Stingaci E.P.; Macaev F.Z. VII All Russian conference «Chemistry and medicine, Orgchimed - 2009» together with young scientific workshop. Russia, Ufa, 2009, 211.

[148]. Sargorovschi V.; Sucman N.; Iudin T.; Stingaci E.; Macaev F. Chem. J. Moldova, 2010, in press. 